\title{
THE HISTORY OF THE WALLED (FORMAL) GARDEN AT BENMORE BOTANIC GARDEN
}

\author{
David Gray ${ }^{l}$
}

\begin{abstract}
ABSTR ACT
The 2.02 ha site containing the Category B listed Walled Garden at Benmore is currently the subject of a major redesign proposal and active fundraising programme. The purpose of this article is to raise the profile of the project by investigating and highlighting the historical development of the site. This retrospective study is also intended as a support to contemporary redevelopment plans and as a demonstration of how the past underpins and informs the future.
\end{abstract}

I am frankly and absolutely for a formal garden ... It is a small piece of ground enclosed by walls ... There is not the least attempt to imitate natural scenery (Phillpotts, 1906, p. 54).

\section{INTRODUCTION}

Benmore Botanic Garden is located on the Cowal peninsula within the district of Argyll and Bute on the west coast of Scotland. The 48.5 ha policies surrounding Benmore House have benefited from almost 200 years of tree and other ornamental planting. Successive generations of private landowners invested heavily to improve the appearance and productivity of the estate. The documented involvement of the Royal Botanic Garden Edinburgh (RBGE) at Benmore commenced in 1925 (Anon., 1925b).

The development and history of Benmore has been chronicled extensively (Bown, 1992). This article reviews almost exclusively the timeline regarding the origins and various adaptations of the late 19th-century Walled Garden located towards the northern extremity of the site.

\section{HISTORICAL BACKGROUND}

Walled gardens providing privacy and protection date back to the earliest of recorded civilisations (Goode et al., 1991). In strictly Scottish terms, reliably inclement weather, together with frequently short growing seasons, made the walled garden a necessity to productive gardening (Campbell, 2007). This accepted wisdom was evident as early as 1683 when John Reid (1655-1723) stated in his Scots Gardener regarding the

1. David Gray is a Senior Horticulturist at Benmore Botanic Garden. Address: Benmore Botanic Garden, Dunoon, Argyll, PA23 8QU, UK. Email: dgray@rbge.org.uk 
construction of kitchen gardens that "brick is best, next is stone and lime" (Reid, 1988 [1683], p. 24).

Initially gardens tended to be attached to the main dwelling; however, by the early 18th century the proximity of high-walled kitchen gardens adjacent to the mansion house was deemed unfashionable, prompting slightly more remote locations (Campbell, 2006).

Walled gardens in Scotland typically "combined practicality and pleasure producing decorative flowers as well as fruit, vegetables and herbs" (Campbell, 2007, p. 194). The early success and continued popularity of the format from the middle of the 18th century onwards ensured recognition of the walled garden as perhaps the most typical component of Scottish estates (Cox, 1935).

Walled gardens attached to modern or refurbished castles enjoyed a revival around the turn of the twentieth century; this resurgence enthusiastically promoted the walled garden as the national style of garden in Scotland (Brogden, 1981).

\section{EARLY HORTICULTURE AT BENMORE}

An extract from the New Statistical Account of Scotland describing the residence of George R. Wilsone as having "well arranged and finished grounds [that] both please and surprise" (Mackay, 1845, p. 610) provides perhaps the earliest horticultural reference to Benmore.

From about 1850 onwards much of Scotland was accurately surveyed for the first time at a large scale. The resultant beautifully engraved and later lithographed OS First Edition series at a scale of 6 inches to 1 mile provides an invaluable landscape history resource (Dingwall, 1995). The relevant Argyllshire Sheet (1869) records the location of a small walled garden to the south of Benmore House (Fig. 1). The map also includes details of the footpaths quartering the 1.055 acre $(0.43 \mathrm{ha}$ ) site into a classic 'four-square layout'. No other documented information or images survive regarding the original walled garden at Benmore.

The initial survey information resulted in the preparation of a larger-scale series of maps. The OS First Edition for Argyll \& Bute (1869) at a scale of 25 inches to 1 mile notes the position and layout of the Courtyard Offices attributed by Walker (2000) to David Thomson (1830-1910). Within the adjacent 13.133 acre (5.3 ha) compartment of relatively flat "ornamental ground" (James, 1869) to the north-east of Benmore House is the site of the future Benmore Walled Garden (Fig. 2).

\section{THE ORIGINS OF THE BENMORE WALLED GARDEN}

Glasgow-born James Duncan (1834-1905) purchased Benmore House and its 12,500 acre (5,058 ha) estate for $£ 105,000$ in October 1870. Duncan's proprietorship of Benmore lasted 19 years and featured unprecedented levels of energy, vision and investment (Watson, 2010). All available records leave little doubt that it was James Duncan who initiated and financed the construction of the Benmore Walled Garden. 


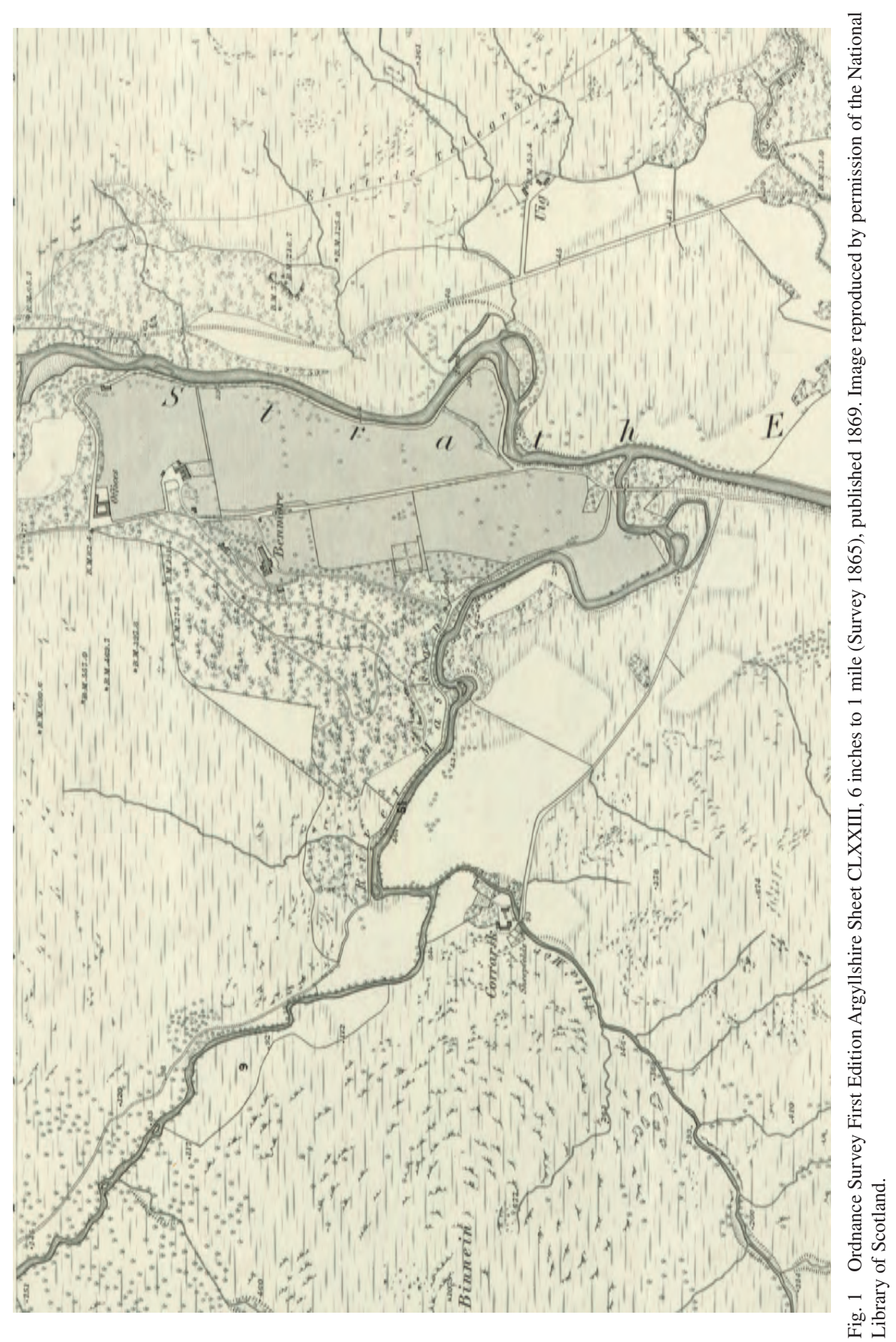




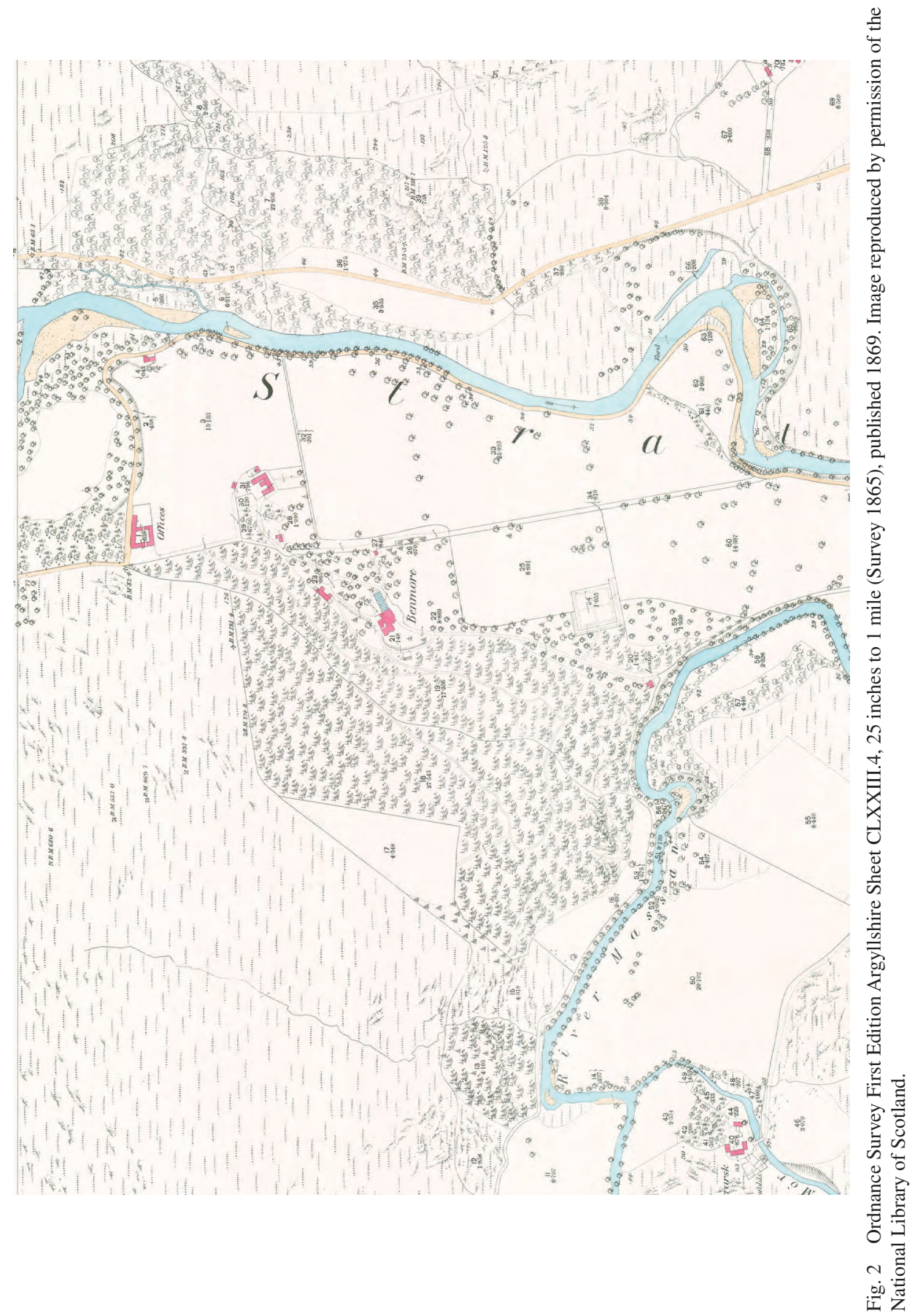


A dearth of early archive documentation means that determining responsibility for the original design concept to create the irregularly shaped Walled Garden at Benmore is challenging. The preservation of anonymity regarding design is a situation not unprecedented throughout early Scottish garden history (Hadfield, 1979). Head gardeners rarely receive credit for innovation, but it has been accurately noted that "much garden design has been undertaken, gradually and instinctively, by plantsmen, gardener-craftsmen and (imaginative) owners" (Davis, 1996, p. 5). It seems a reasonable assumption that the initial development of the Benmore Walled Garden progressed in such a patron-led manner.

\section{EARLIEST IMAGE AND WALL CONSTRUCTION}

Viewed from the south-east the earliest available image of the Walled Garden dates from approximately 1870 (Fig. 3). The grainy shot includes the fledgling Redwood (Sequoiadendron giganteum) Avenue and the Courtyard Offices or steading. All the surviving garden walls appear to be complete.

The tallest section of wall to approximately $3.6 \mathrm{~m}$ is constructed from squared rubble and forms the shared boundary between the Garden and adjacent courtyard before stepping down to substantial chamfered and finialled gate piers at the north wall midpoint. The $3.3 \mathrm{~m}$ tall north-east and east walls eventually step down further to the long curve of the lower 1.1-1.7 m tall partially sunken south wall. The south wall contains a double ornamental gateway opposite the north wall entrance. All the latter walls are mortar random rubble in construction. All walls feature a heavy dressed semi-

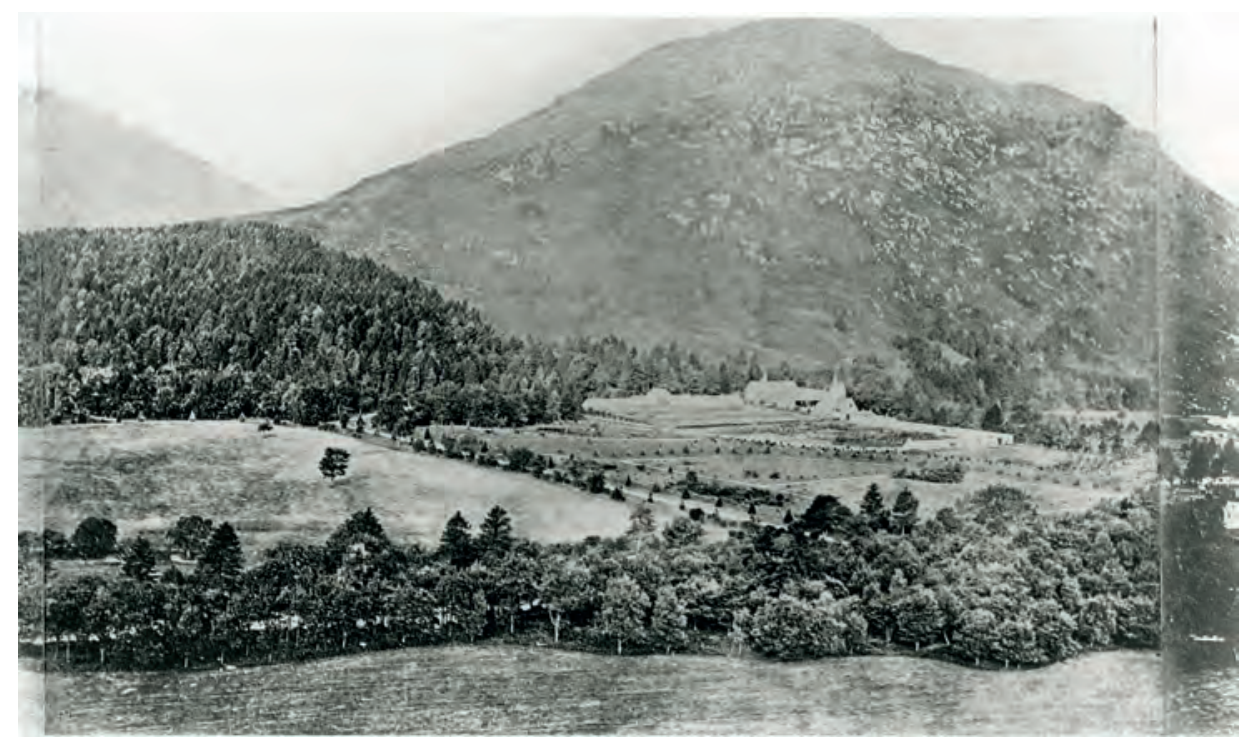

Fig. 3 Benmore policies from south-east, c. 1870. Image reproduced courtesy of Younger Family Archive. 
circular ashlar or flat coping. Surviving stayed metalwork suggests the height of the south wall may have been extended by strained horizontal wires.

The most prominent feature in the 1870 image is the western boundary of the Walled Garden, which is formed by a substantial glasshouse. A slightly later catalogue reference describes:

A 325 feet long range of glasshouses (with) the conservatory in the centre being 30 feet wide and the other portions 24 feet and 20 feet wide. There is within this range of glass an orchard house for plums, azalea house, three vineries and stove house ... two terraces with steps at the walks lead from the conservatory to the garden. (Lyall Watson et al., 1889, pp. 13-14)

\section{FRAGMENT VIEW}

The provenance and date of the next archive photograph is uncertain (Fig. 4). The partial or fragment view from the north-west boundary demonstrates a ferocious rate of development. The classic axial layout and majority of the historic Walled Garden features are all recognisable. Mature hedges define well-established herbaceous borders. Garden

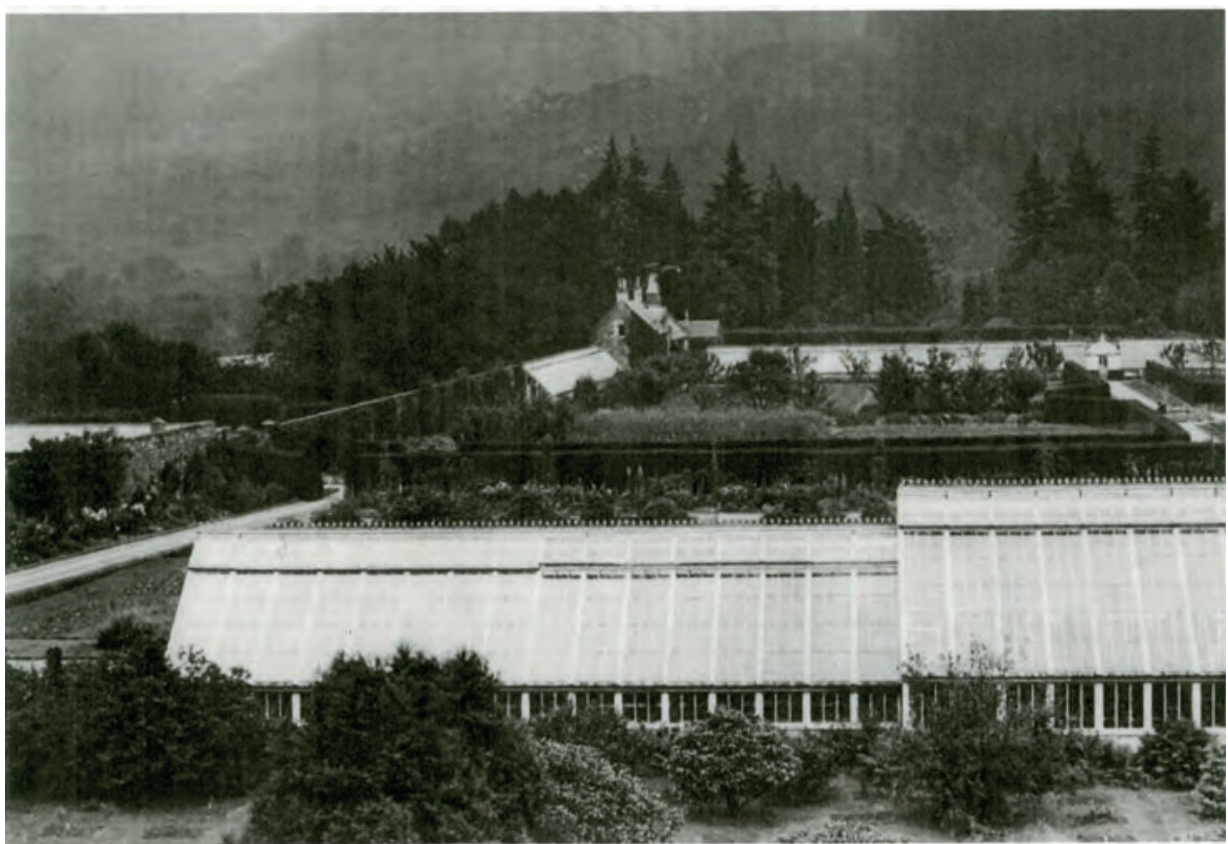

Fig. 4 Black-and-white view from west (fragment, undated). Miscellaneous photograph in Benmore Curator's office, kindly made available by Peter Baxter. It is quite conceivable that this image may post-date the demolition of the winter garden. 
Cottage and the surviving lean-to teak glasshouse occupy the north-east corner. A further extensive glasshouse range has been added along the west-facing side of the eastern boundary wall. A later review notes that "the productive capacity of the garden is greatly increased by a lean-to peach house, plum house and co, extending along the walls for 436 feet" (Lyall Watson et al., 1889, p. 14). A raised ornamental pond is positioned at the axial junction opposite the glasshouse portico entrance. A later image confirms the bronze 'Boy with Two Dolphins' fountain as an extravagant centrepiece (Fig. 16). Artefact markings confirm that this highly decorative feature was created in 1876 by German-born sculptor Michael Wagmüller RBA (1839-1881).

\section{WINTER GARDEN}

Behind the eastern wall and therefore outwith the boundary of the present-day Walled Garden are the remnants and footprint of a large-scale ornamental water feature. The following description from 1889 is reproduced in its entirety to proclaim the sheer ambition and flaunting grandeur of the former water or winter garden:

The winter garden is a magnificent structure, cruciform in shape. It is over 150 feet in length; the centre portion is 53 feet wide and the ends 32 feet wide, the height of the building being about 30 feet. The centre of this garden is enriched by a very fine Statuary Carrara Marble Fountain which costs $£ 1,500$.

The basin is triangular in form, and at each corner there is a life-size representation of a boy capturing a swan, the swans' heads looking up to a smaller triangular basin and spouting water into it. The pedestal, which is tastefully ornamented with full-sized lotus and lily leaves, is surmounted by a fine female figure, bearing a pitcher on her head, from which water also flows into the basins. The entire fountain is surrounded by a concrete basin about 18 feet in diameter, the overflow being carried off by a small stream running down the centre of the garden, giving the place a delightfully cool appearance.

Gold and silver fish and trout disport in the larger basin and in the stream, which is shaded with rare ferns.

The House is stocked with what is perhaps the finest collection of Camellias in Scotland, some of the trees being about 15 feet high. There are also some fine specimens of Eucalyptus globulus, the Lemon-Scented Eucalyptus, Tree Ferns, and other rare Tropical Plants.

The west side of the building is covered with ferns which add to the beauty of the scene. (Lyall Watson et al., 1889, p. 13)

A hand-coloured postcard view from the very early 20th century (Fig. 5) together with a surviving black-and-white image (Fig. 6) affirm the towering splendour of the winter garden. The serenity of the interior arrangement is also revealed (Fig. 7). 


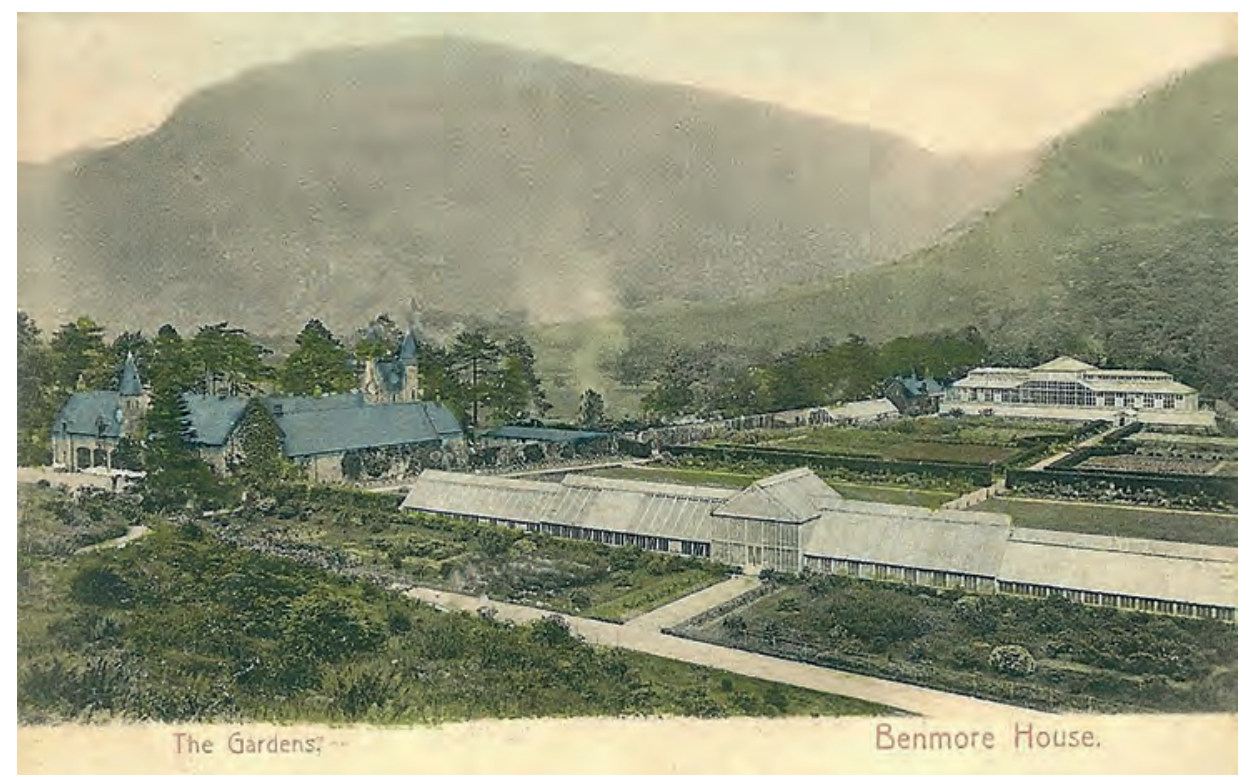

Fig. 5 Hand-coloured postcard view from west, c. 1902. Kindly made available by Ann Galliard via Jane Kelly.

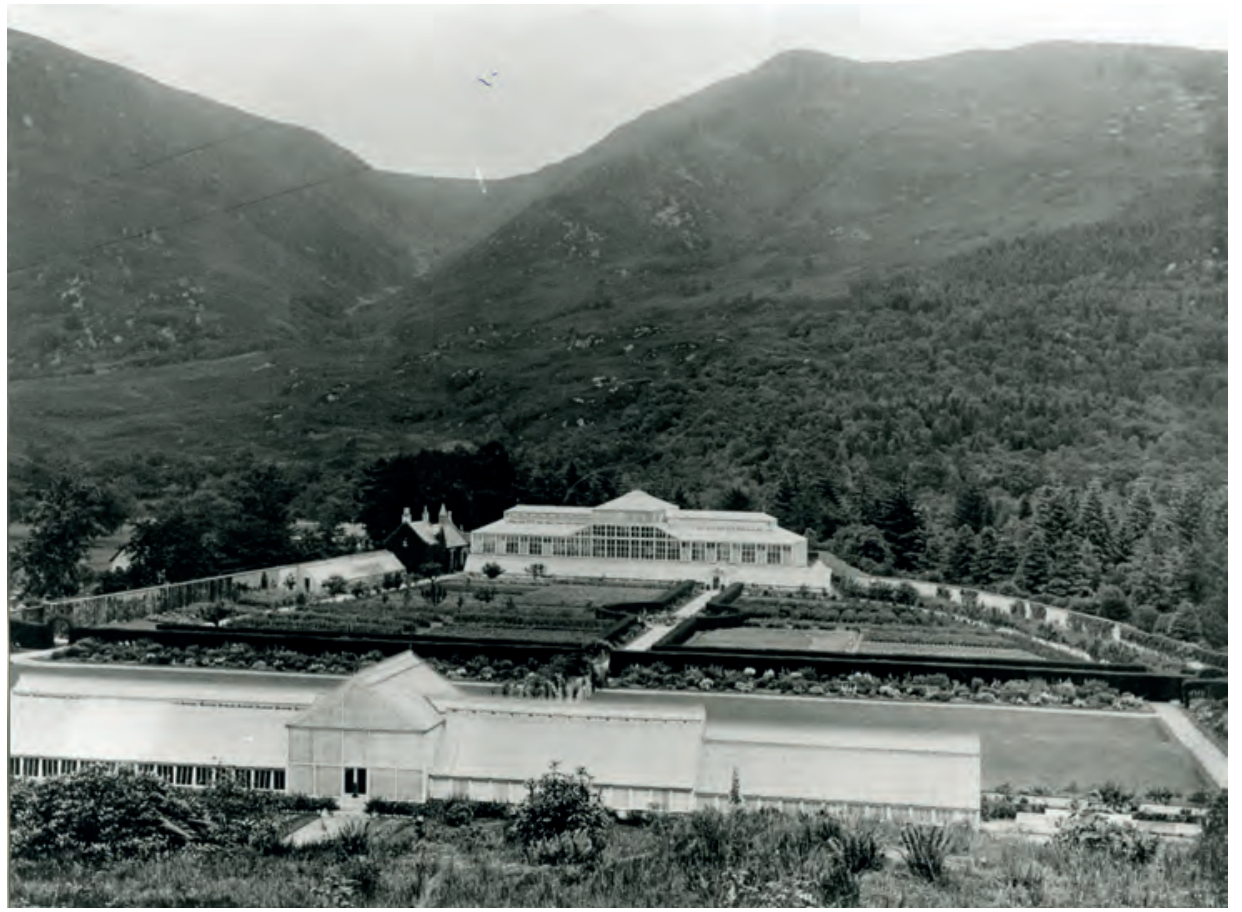

Fig. 6 Greenhouses and Walled Garden at the Benmore estate in the 1890s. Image reproduced courtesy of Younger Family Archive. 


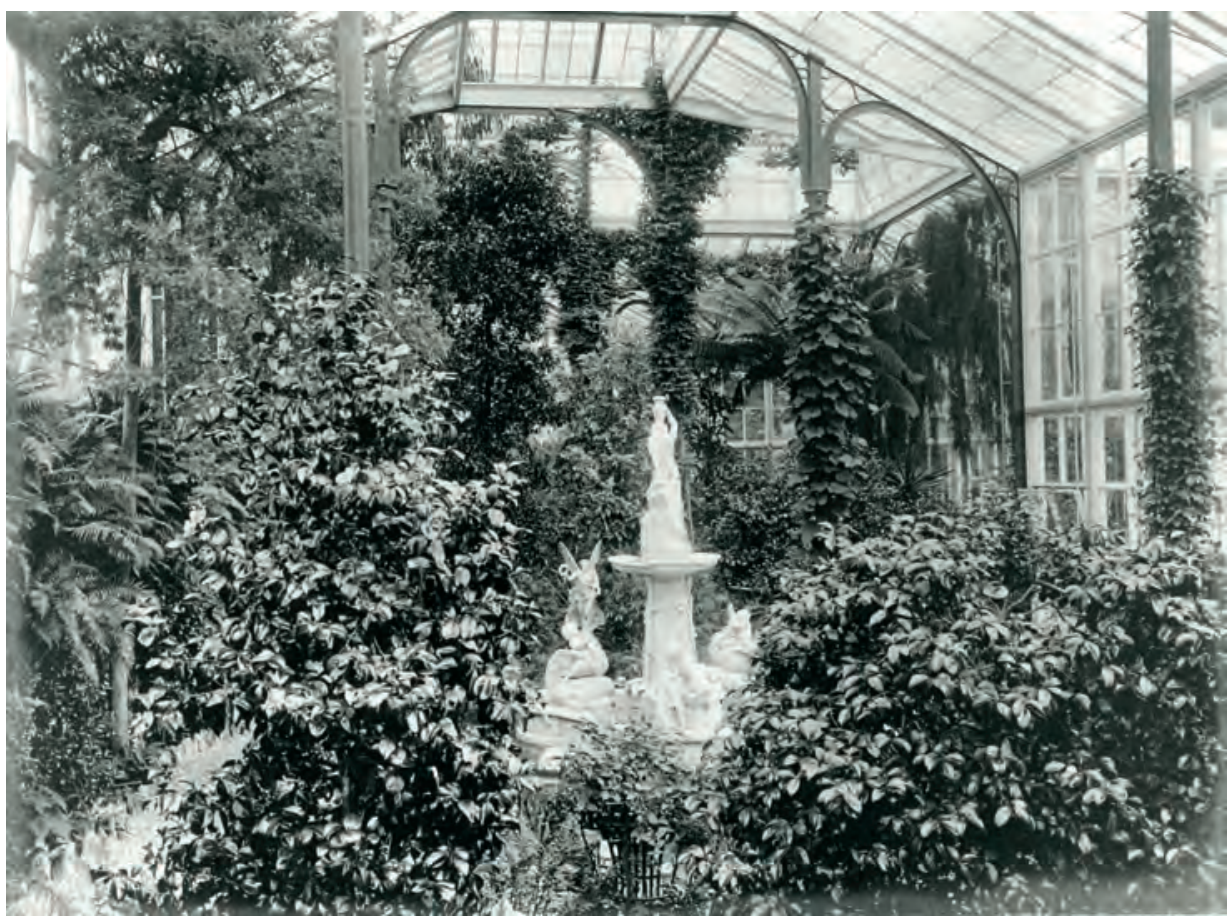

Fig. 7 German-designed Carrara marble fountain in the greenhouse c. 1890s, Benmore Walled Garden. Image reproduced courtesy of Younger Family Archive.

\section{JAMES BOYD \& SONS LTD OF PAISLEY}

In the early 1870s, James Duncan commissioned James Boyd \& Sons Ltd of Paisley to construct a stone wall and glass barrel-roofed fernery overlooking the River Massan at Benmore (Anon., 1875). The design of the fernery was adapted from a generalised plan modified to satisfy the specific requirements of the site (Anon., 1875).

The only remaining glasshouse in the present-day Walled Garden is the Teak House located in the north-east corner. Screwed at the top of the entry door is a manufacturer's plate that reads: James Boyd \& Sons Ltd Horticultural Builders \& Heating Engineers Paisley (Fig. 8).

The firm of James Boyd \& Sons Ltd was founded in 1826. The abolition of tax on glass in 1848 proved a stimulus to business, prompting a move to larger, permanent workshops at MacDowall Street (Paisley) in 1869 (Robertson et al., 2014). The business was promoted within publications such as the Glasgow Building Trades Exchange (Fig. 9). A celebrated contract from this period was the 1873 relocation (with extensions) of the Kibble Palace from Coulport House to Glasgow Botanic Gardens (Curtis, 1999).

A later company catalogue, dated 1905 (Fig. 10), detailed best-quality seasoned red pine or most durable teak wood as construction materials. The firm offered a full design, 


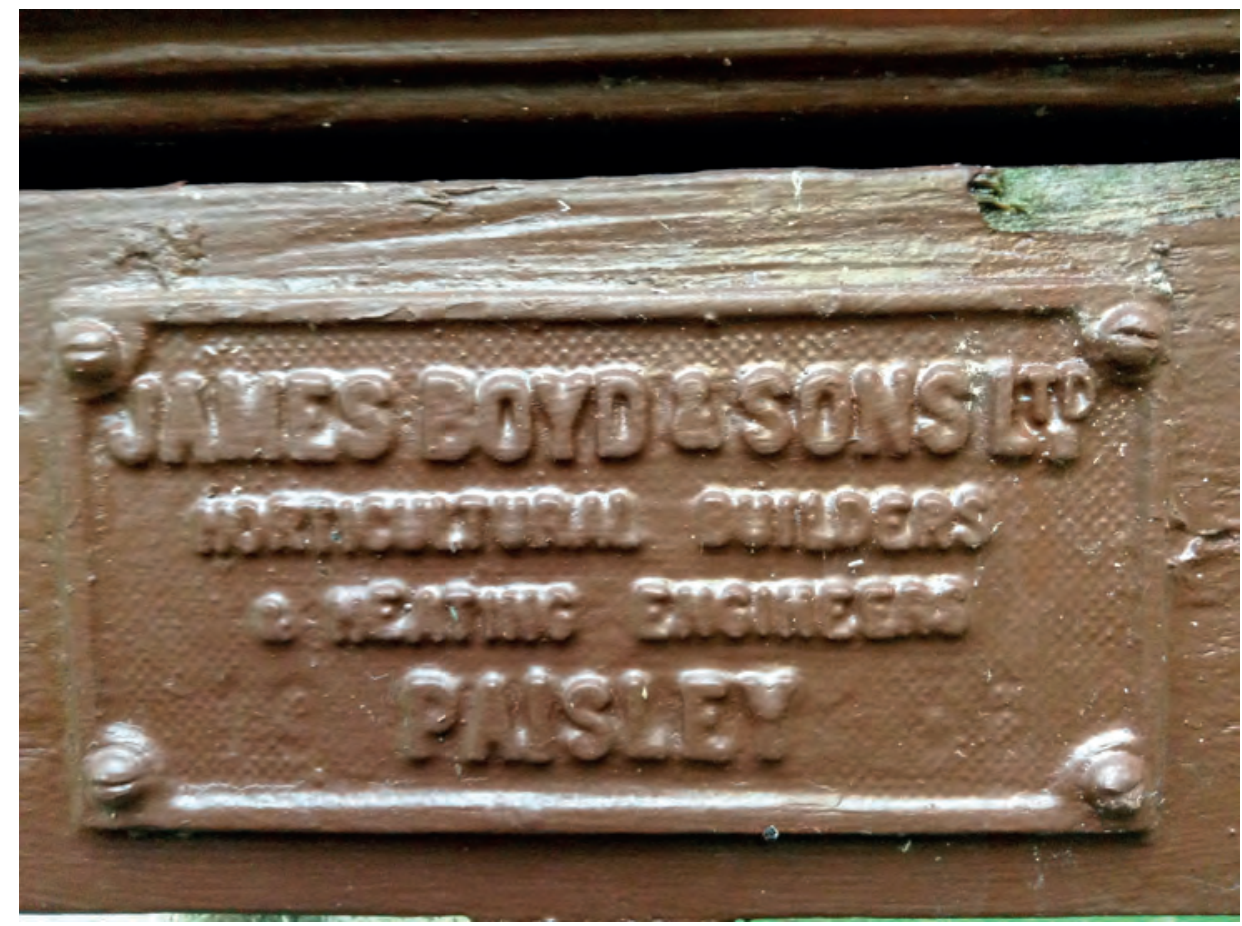

Fig. 8 James Boyd \& Sons Ltd manufacturer's plate, Teak House. Photograph: David Gray.

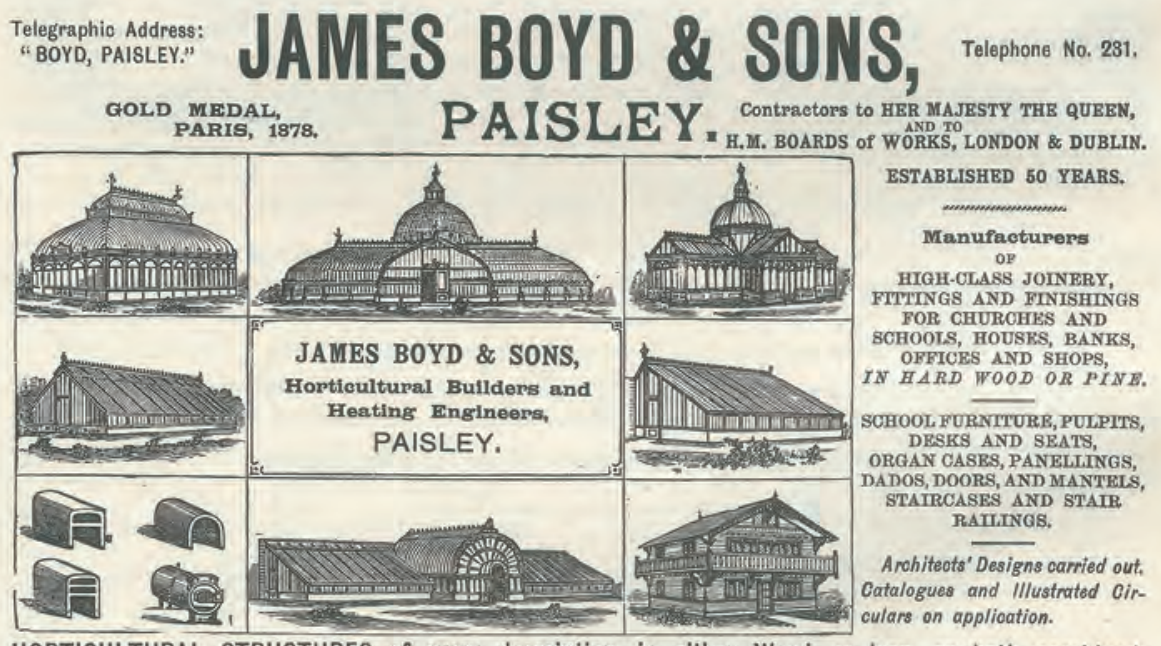

HORTICULTURAL STRUCTURES of every description, in either Wood or Iron, or both combined. WOODEN CHAPEIS, SHOOTING LODGES, COTTAGES, TENNIS COURTS, VERANDAHS, \&C.

HOTHOUSES IN TEAK WOOD, as supplied for Botanic Gardens at Glasgow, Glasnevin, Cape Town, Port Elizabeth, Ceylon,
Oxford and Cambridge. Our Speciality is substantial, durable, and tasteful workmanship, with all real improvements. Plans and Estimates fornearded on receipt of particulars. Orders for shipment carefulty fitted and packed, and delivered f.o.b. Glasgons.

Fig. 9 Advertisement for James Boyd \& Sons Ltd, Glasgow Building Trades Exchange (1896), p. 146. Image T-ARD17/36 reproduced courtesy of Glasgow City Archives. 


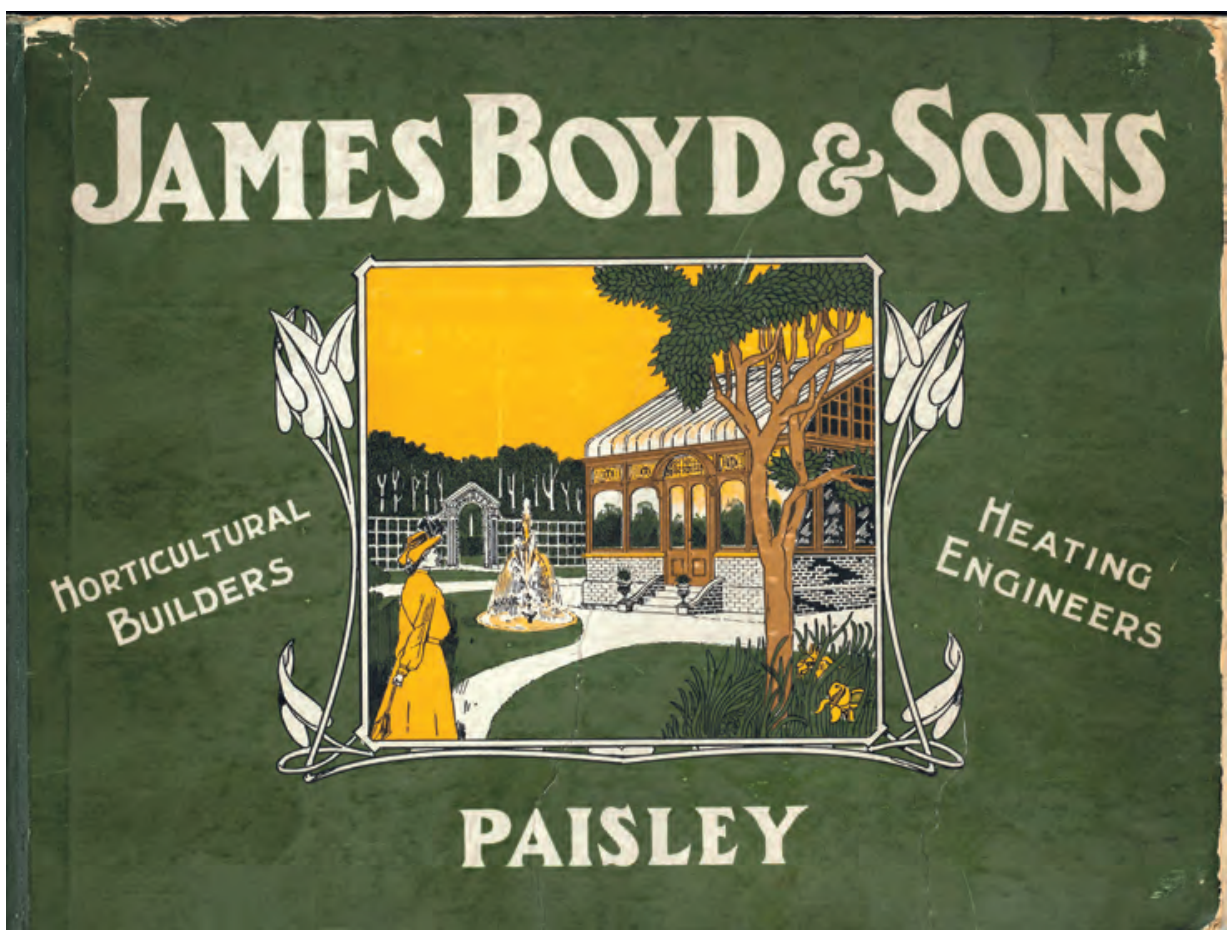

Fig. 10 An Illustrated Catalogue, James Boyd \& Sons, Horticultural Builders and Heating Engineers Paisley (1905). Image reproduced by permission of the National Library of Scotland.

manufacturing and installation service employing "skilled workmen for all branches of the trade thus avoiding the expense and trouble of sub-contracts" (Boyd, 1905, p. 6). Logistics and distribution presented no problems with "orders carefully fitted, the different parts marked, securely packed, and delivered at the ship's side in Glasgow, whence ships sail regularly to all parts of the world" (Boyd, 1905, p. 7).

Prominent listed clients included Her Late Most Gracious Majesty Queen Victoria, the most Noble Marquis of Bute and Sir Herbert Maxwell at Monreith. Overseas contracts supplied Royal Botanic Gardens at Cape Town, Durban and Peradenyia (Sri Lanka). Closer to home, customers included James Arrol at Finnartmore, Mrs Balfour at Dawyck, James Coates at Dunselma, Alfred W. Cox at Glendoick, James McDouall at Logan and Alexander Bannatyne Stewart at Ascog (Boyd, 1905, pp. 8-12, 34). By the mid-1920s James Boyd \& Sons were a limited liability firm of boilermakers, ironfounders and structural engineers. Hothouse design no longer featured as a speciality, reflecting changed social and economic attitudes after World War I (Robertson et al., 2014).

A noteworthy demonstration of the qualities and capability of James Boyd \& Sons Ltd is provided by the recently restored (2002-2004) Palm House at Glasnevin Botanic 
Garden (Dublin). The structure was originally purchased in 1884 at a cost of $£ 800$ (BGCI, 2006).

In the absence of any other surviving documentary evidence and given the proximity of construction dates regarding the full complement of Benmore Walled Garden hothouses, it seems more than reasonable to suspect that horticultural builders and "winter garden specialists" (Boyd, 1905, pp. 13-44) James Boyd \& Sons Ltd was the principal contractor involved throughout the entire glasshouse design, manufacture and construction process. Indeed, it may even be appropriate to consider speculating further regarding the possibility that the same company acted as the design consultant and supplier of the masonry workforce throughout the entire creative or early construction phase of the Benmore Walled Garden.

\section{SUMMARY OF EARLY DEVELOPMENT}

In 1883, there were signs that Duncan's financial situation was unstable; after this year he never stayed at Benmore again and would eventually dispose of his Argyllshire estate in 1889 (Watson, 2010).

The scale and breathtaking celerity of Duncan's achievement at Benmore was astounding. The horticultural excellence attained within the Walled Garden is perhaps best summarised by two contemporary reviews:

The range of greenhouses and the extent of ground covered with glass is wonderful [with a vast array of] plants and flowers, stove plants, greenhouse plants, bedding out plants, border flowers and annuals of every kind and description. (Clerk, 1878, p. 35)

The gardens and greenhouses are of themselves sufficient to attract the admiration of visitors to the locality. (Stalker, 1883, p. 141)

THE YOUNGER FAMILY AT BENMORE

For the sum of $£ 110,237$ Henry John Younger (1832-1913) of the famous Edinburgh-based brewing family acquired the estate of Benmore in late 1889 (Watson, 2010). It is he who is credited with introducing the first Rhododendron plantings to Benmore (Younger, 2004).

The Younger years coincided with the publication of the OS Second Edition Argyllshire Sheet (1899) at a scale of 25 inches to 1 mile. The layout of the modern or present-day Walled Garden is largely recognisable in this revised and updated map (Fig. 11).

The location and presence of all the original elements of Duncan's Walled Garden as previously described are confirmed; a boundary path circumnavigates the margins, the change of level in front of the west conservatory is recorded whilst slight irregularities of the axial layout are clearly visible. 


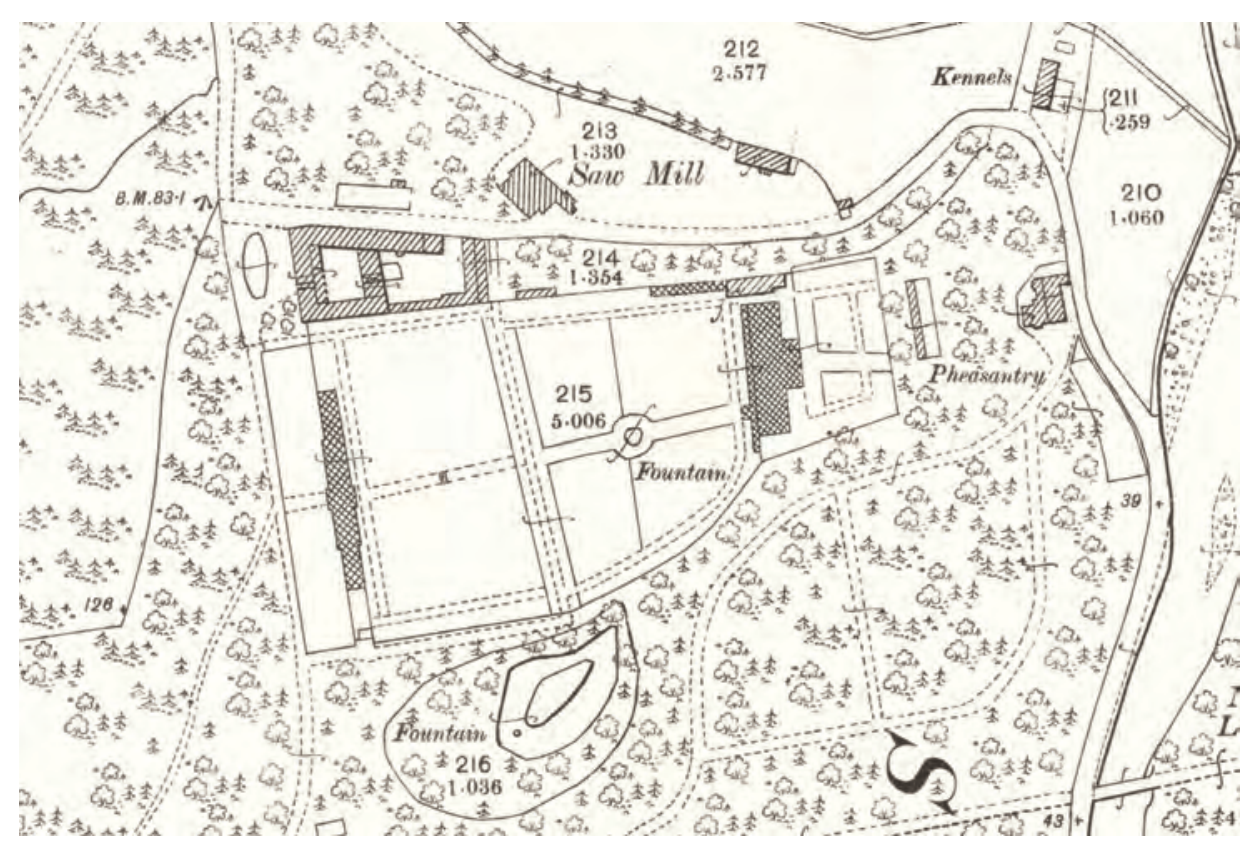

Fig. 11 Detail from Ordnance Survey Second Edition Argyllshire Sheet CLXXIII.4 (Dunoon \& Kilmun Parish), 25 inches to 1 mile (revised 1898), published 1899. Image reproduced by permission of the National Library of Scotland.

The integrity of Duncan's design is further confirmed by a surviving postcard image courtesy of photographer Thomas Faulkener Mackay who ran a studio from Claddy House, Sandbank between the years 1907 and 1911. Included in the elevated view from the west are three gardeners, identified by their white shirtfronts and sleeves, tending the borders (Fig. 12).

According to calculations, ornamental and productive walled gardens required two to three gardeners per acre (equivalent to five to eight gardeners per hectare) to operate efficiently (Campbell, 2006). It has been recorded that the largest section of the Benmore estate workforce was the gardening staff, who numbered around 40. Much of their effort centred on the Walled Garden with its vegetables, elaborate bedding schemes and glasshouses. The demands of such a payroll clearly troubled Henry John Younger; to save money, he eventually ordered the demolition of the winter garden leaving the "girlie" fountain to the mercies of the weather (Younger, 2004).

Henry John Younger was succeeded by his son Harry George Younger (1866-1951) in 1913. The latter cited heavy death duties as a reason for cutting outdoor staff. World War I also took its toll on Benmore staff and enthusiasm (Younger, 2004). A combination of personal circumstances and escalating maintenance costs resulted in Harry George Younger eventually gifting his Benmore estate of 10,000 acres (4,047 ha) to the newly established Forestry Commission (Anon., 1925a), subject to certain reservations. 


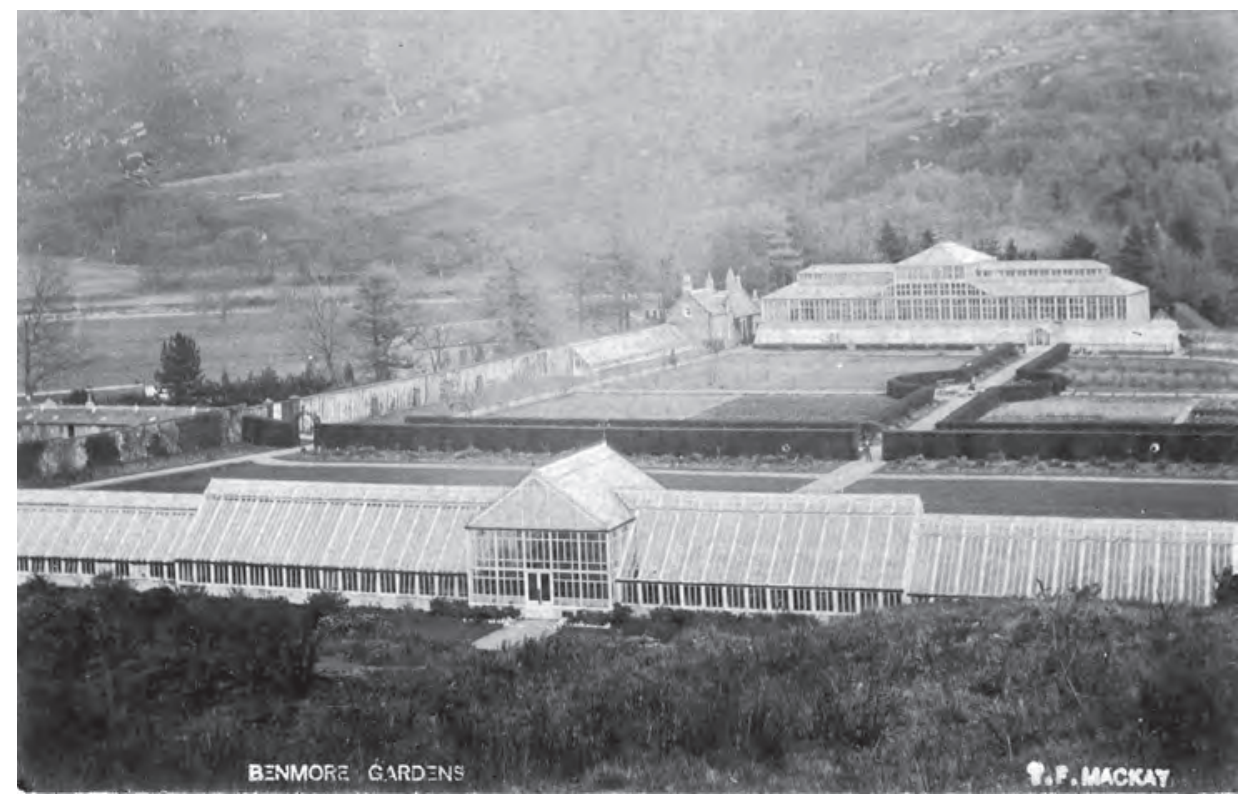

Fig. 12 Black-and-white postcard view from west, T.F. Mackay, c. 1910. Author's collection.

The following extract from The Scottish Gardener and Northern Fruitgrower recounts an excursion to Benmore made by the Glasgow and West of Scotland Horticultural Society in June 1924. It provides a snapshot of the Benmore Walled Garden and an appropriate conclusion to the patronage of the Younger family:

Inside the walled enclosure everything is done in the best style, all crops showing the art of the masterhand and all being in a high state of excellence.

As in the outdoor garden so also in the glasshouses on every side there is evidence of high culture. Carnations and Pelargoniums were particularly fine, and one noted a very promising house of the more useful Tomato and French Beans. Grapes were showing exceptionally well, as also were the Peaches and Nectarines. Passing through the Carnation corridor one enters a perfect fairy garden complete with Lily pools, fountain, wall garden, Erica beds and great breadths of moisture-loving primulas such as $\mathrm{P}$. pulverulenta.

No report would be complete which did not contain a reference to a few striking plants noted on the wall of the kitchen garden behind a most charming herbaceous border. On the wall particularly noticeable were Magnolia conspicua, Choisya ternata and Solanum crispum, each fine big specimens ... The party was most hospitably entertained to tea. (W.D.B., 1924, p. 33) 


\section{RBGE AT BENMORE}

The first documented consignment of plants from RBGE arrived at Benmore in 1925 (Anon., 1925b); however, the gifting of Benmore was a protracted affair that took several years to conclude (Younger, 2004). It was late 1928 before the 90 -acre (36.4 ha) Younger Botanic Garden, under the guidance of Regius Keeper William Wright Smith (1875-1956), was eventually realised (Fletcher \& Brown, 1970).

\section{EARLY FORESTRY COMMISSION GLASS PLATE IMAGES}

As early as March 1925 Regius Keeper William Wright Smith was eager to secure photographs of Benmore and its neighbourhood (Wright Smith, 1925). This may be a reference to a box of early Benmore glass plates dated c. 1920s, now held in the RBGE archives. The Walled Garden features among this collection, with a standard view from the high ground to the west accompanying other images of the functioning pond and winter garden fountains.

\section{RMA COLLECTION}

The most remarkable photographic archive regarding Benmore is that amassed by RBGE employee Robert Moyes Adam (1885-1967). Adam started his RBGE career as an Assistant Head Gardener before attaining the position of Assistant in the Studio in 1915 (Paterson, 2013). Over a period of 35 years he gained a reputation as one of the country's foremost landscape photographers (Bown, 1992). He retired from the Garden in 1949 (Paterson, 2013).

Among the 175 images of Benmore and the surrounding area are 29 iconic views of the Walled Garden dated 1928-1930 (Appendix). These images provide perhaps the most complete review of the area ever undertaken. The surviving glasshouses feature prominently with immaculate borders, timber pergolas and gravel paths competing with tightly clipped yew (Taxus baccata) hedges for clarity of line. Long shots from the slopes of Ben A'Cruach provide an aerial overview (Figs 13-18).

\section{COMMENTARY BY FIRST GARDEN CURATOR}

RBGE Service Roll \& Employment Records note that John White (1889-1943) joined as a probationer in December 1912 before enlisting in the 9th Royal Scots two years later. Demobilised in 1919, he completed his final trainee year at RBGE before attaining the position of Head Gardener to Harry George Younger at Benmore. White progressed to the role of RBGE Curator at Benmore (Younger, 2004). A summary of Benmore in 1930 by White provides accompaniment to the Robert Moyes Adam photographic archive: 


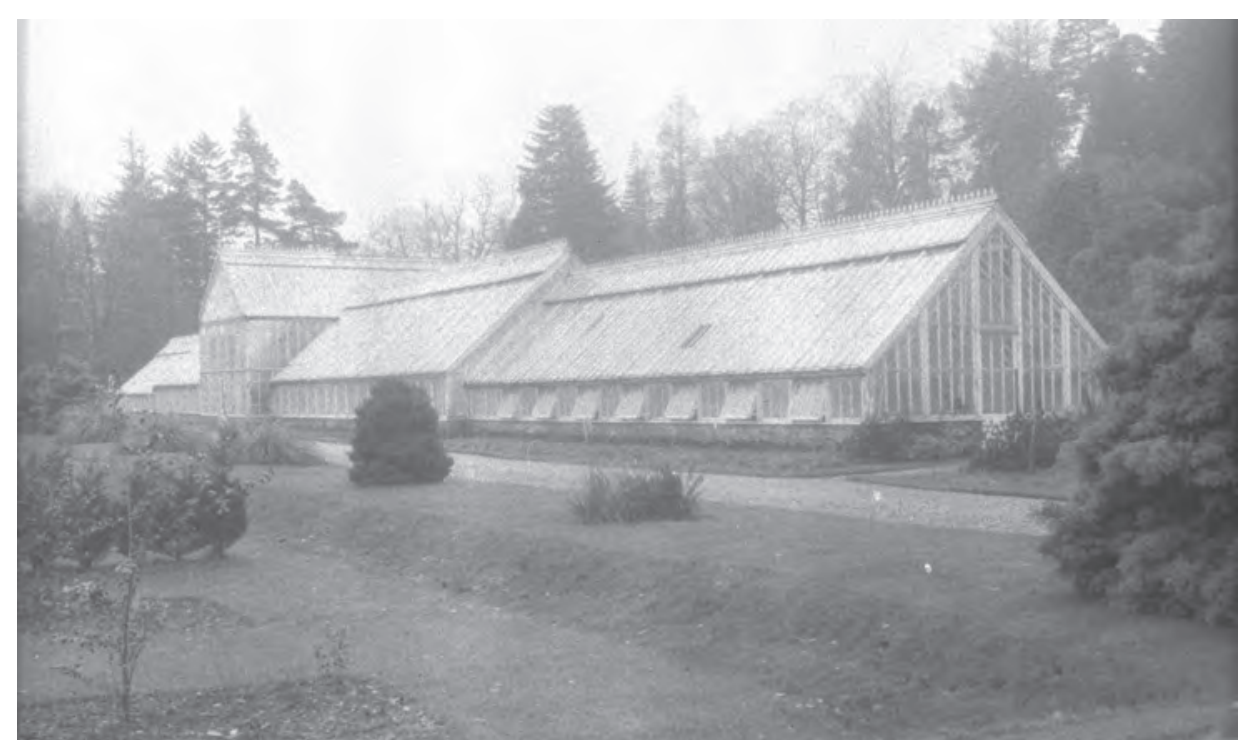

Fig. 13 The Glasshouses, Benmore, 1929. Robert Moyes Adam Image RMA-F-442, reproduced courtesy of St Andrews University Library Archive.

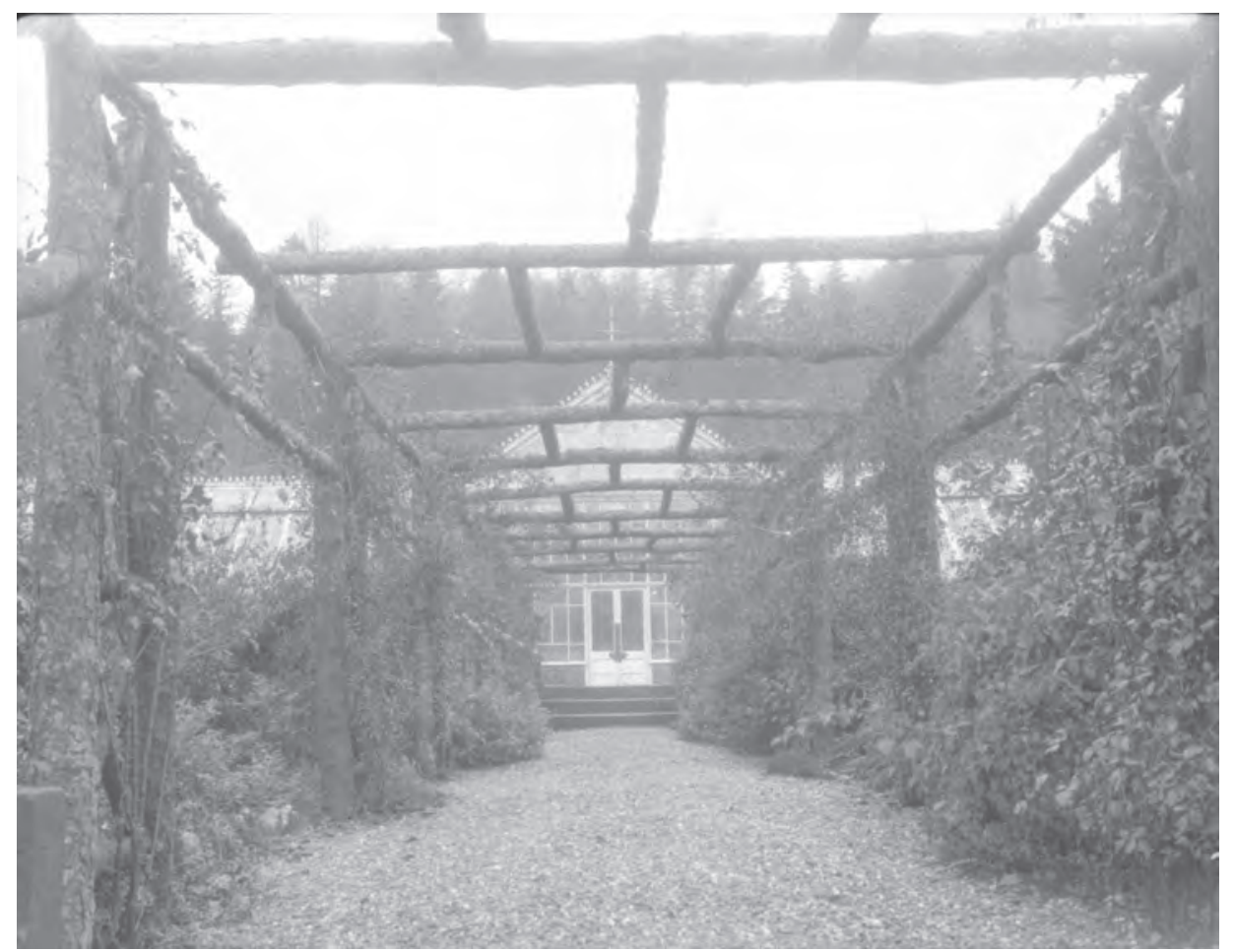

Fig. 14 Pergola, Benmore, 1929. Robert Moyes Adam Image RMA-F-437, reproduced courtesy of St Andrews University Library Archive. 


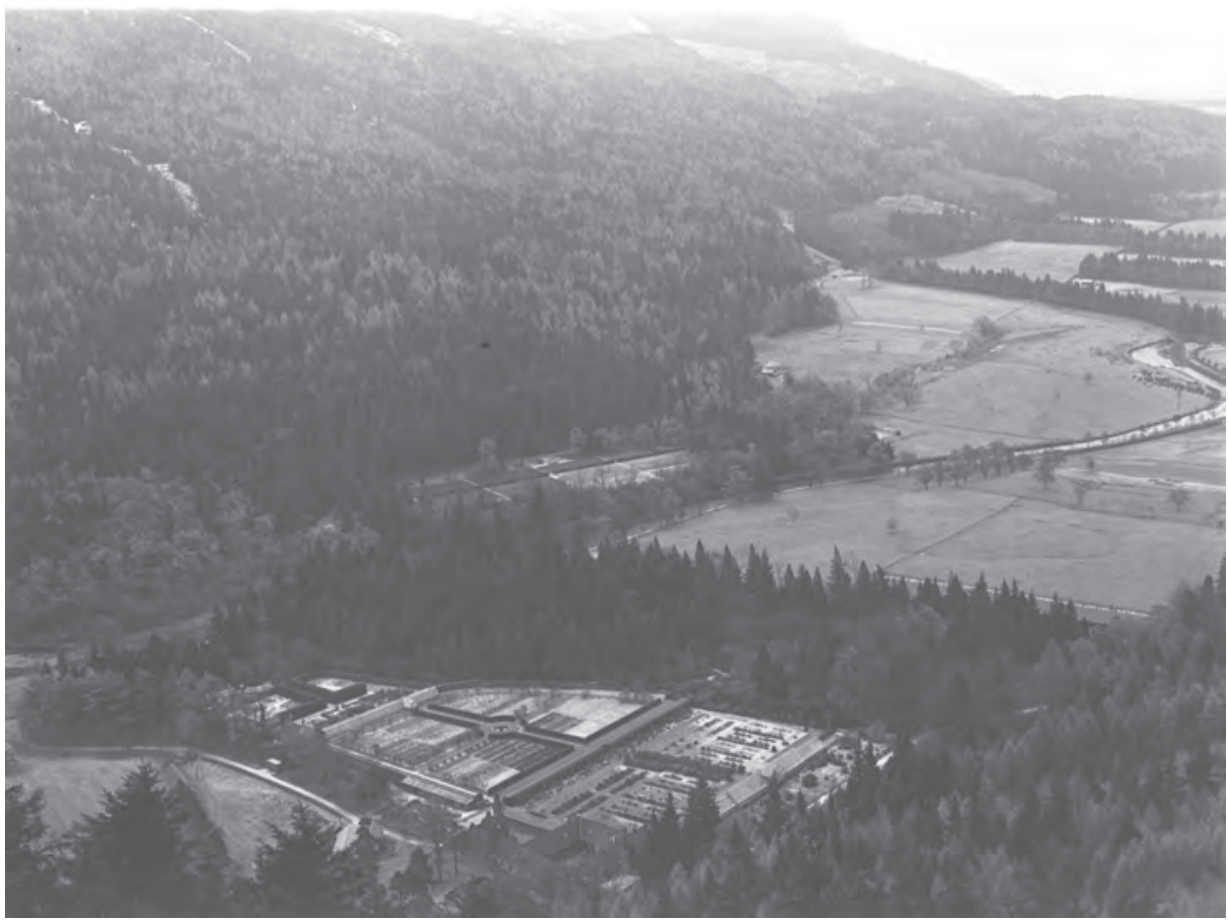

Fig. 15 Benmore Garden, Cowal (from A’Chruach), 1929. Robert Moyes Adam Image RMA-H-2161, reproduced courtesy of St Andrews University Library Archive.

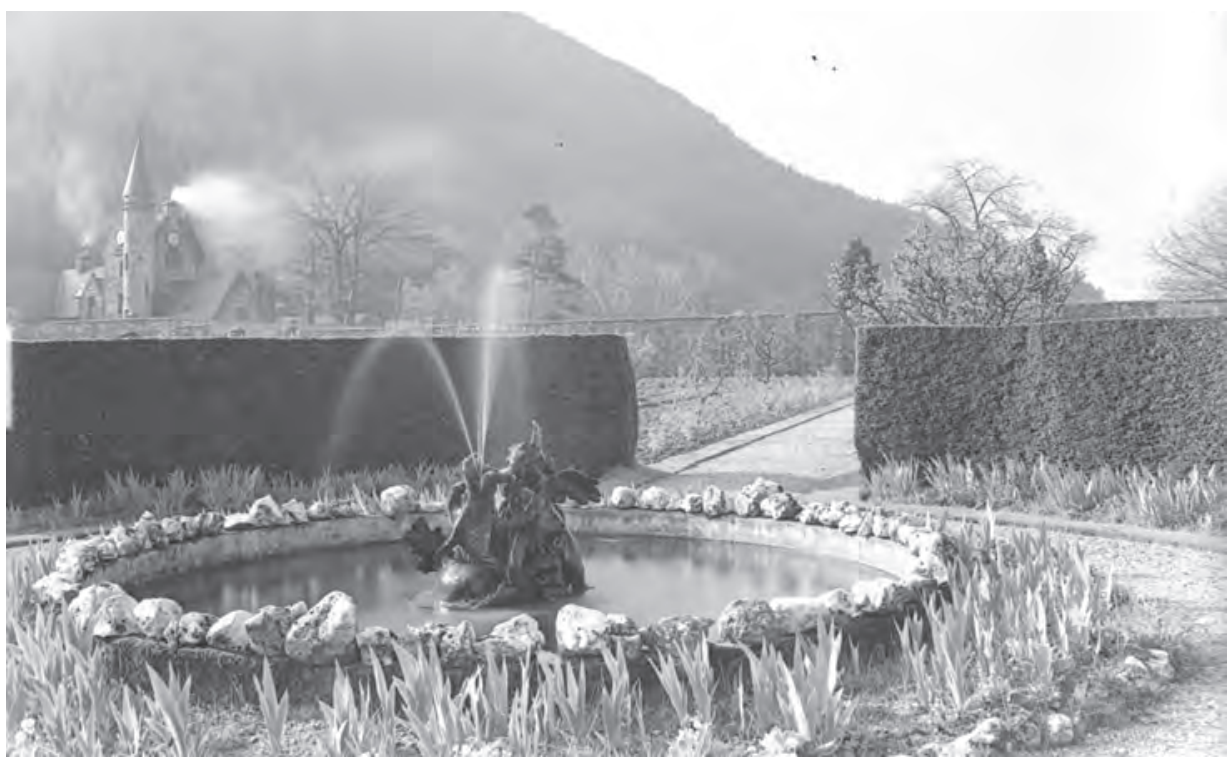

Fig. 16 The Fountain, Benmore, 1930. Robert Moyes Adam Image RMA-H-2312, reproduced courtesy of St Andrews University Library Archive. 


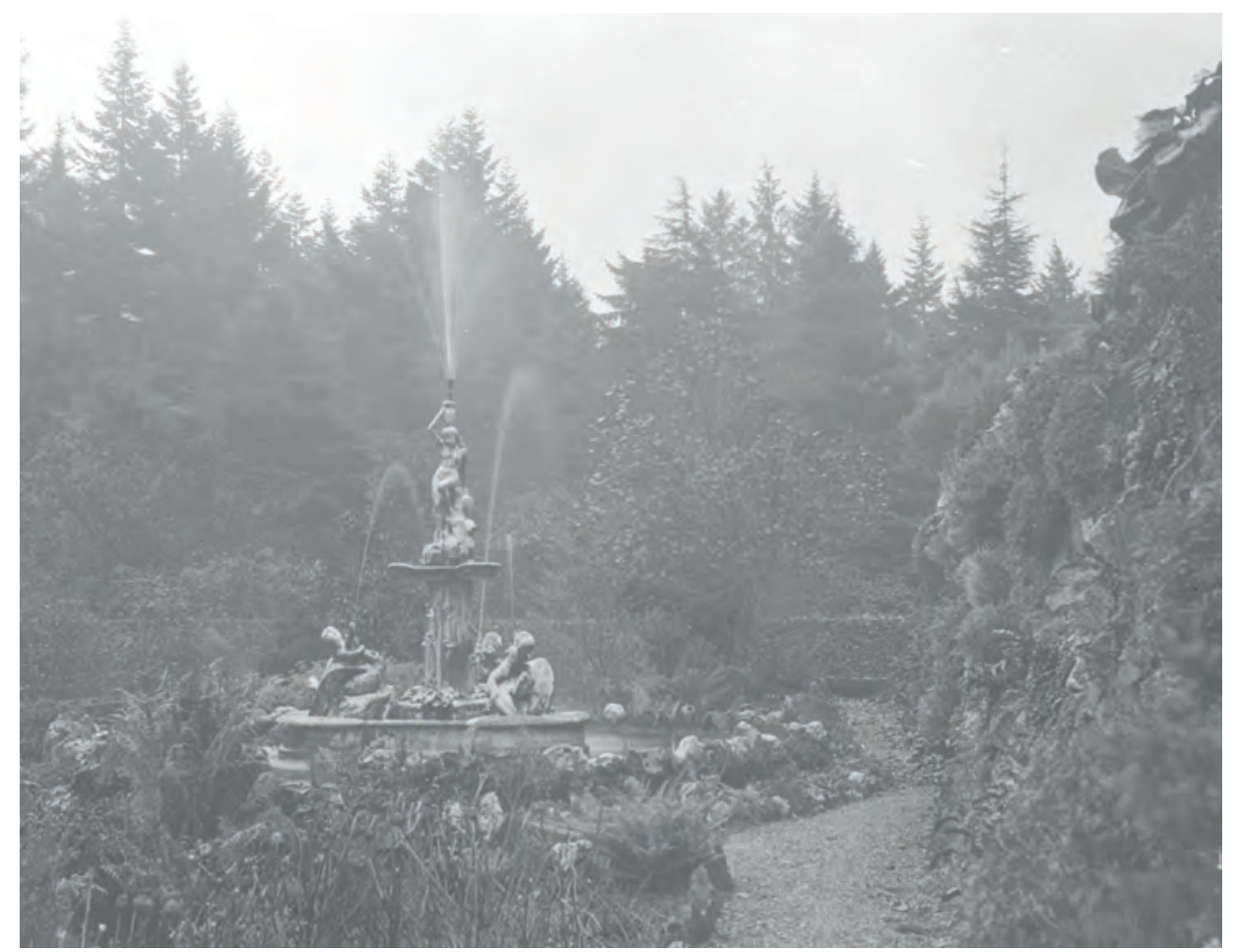

Fig. 17 Fountain, Rock Garden, Benmore, 1929. Robert Moyes Adam Image RMA-F-433, reproduced courtesy of St Andrews University Library Archive.

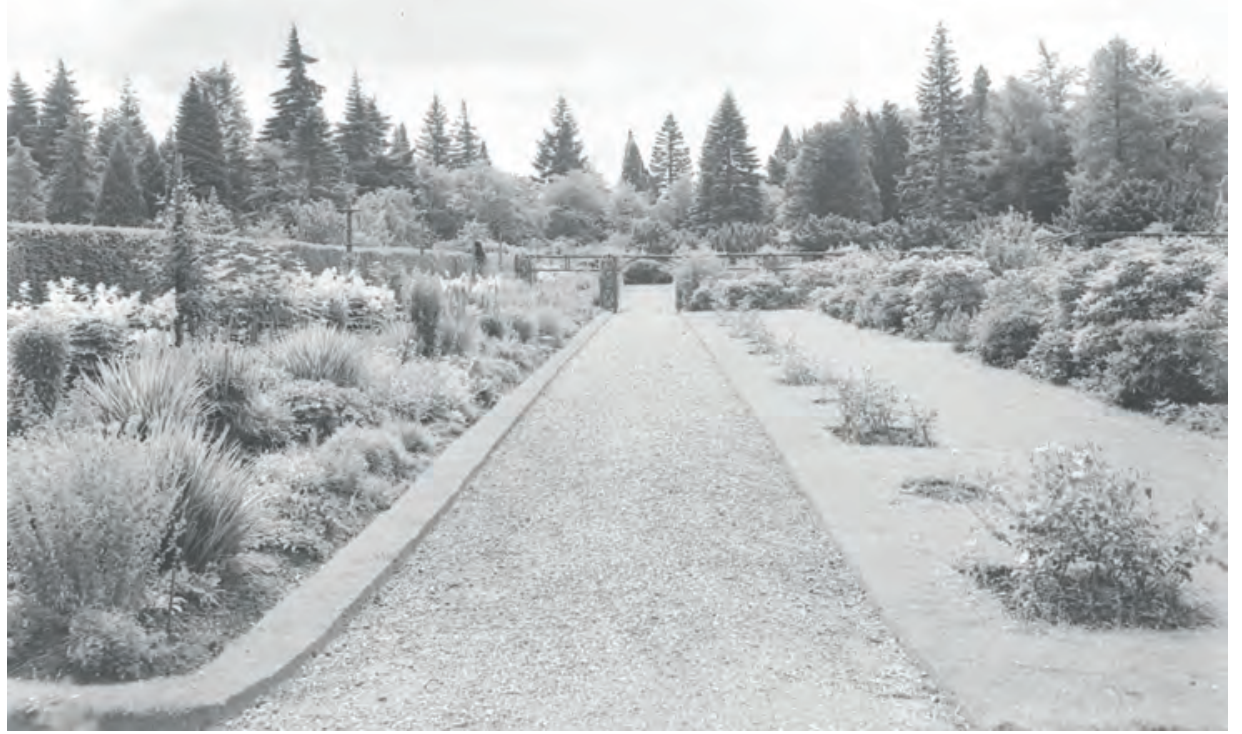

Fig. 18 The Garden, Benmore, 1930. Robert Moyes Adam Image RMA-H-2367, reproduced courtesy of St Andrews University Library Archive. 
The garden proper is divided into three parts, the centre portion of which is intersected by Yew hedges. This part, so far, has been devoted to the cultivation of fruit and vegetables. Seedling Rhododendrons were tried here four years ago, but were not a success, probably due to the presence of lime in the soil. The bottom or easterly part is composed principally of what is called the 'Winter Garden'. This used to be a huge glass-house, but it is now demolished during the lifetime of Mr Younger's father. It is now planted with Bamboos, Heaths, Magnolias, etc. Seedling Rhododendrons have also been planted here. The healthier growth is sufficient evidence that conditions are more to their liking than in the vegetable garden.

In the westerly or top part of the Garden we have herbaceous borders, rose pergola, and several rectangular beds containing shrubs and Rhododendrons. The majority of these beds were only planted last spring. Here also are to be found growing against a wall: Abelia floribunda, Berberidopsis corallina, Correa alba, etc. (White, 1930, p. 60)

\section{PLAN FOR THE DEVELOPMENT OF BENMORE (1930-1940) BY DR J.M. COWAN}

RBGE Assistant Regius Keeper Dr John Macqueen Cowan FRSE CBE (1892-1960) was charged with the task of assessing and developing the Benmore policies.

A skilled botanist and forester, the vastly experienced Dr Cowan returned to Scotland in 1928 from lengthy overseas service, latterly as Superintendent of the Royal Botanic Garden Calcutta (Fletcher \& Brown, 1970). A gifted plantsman and prolific writer, he edited The Journeys \& Plant Introductions of George Forrest (1952). He revealed further his horticultural leanings by accepting the post of Garden Advisor with the National Trust for Scotland (based at Inverewe) upon his retirement from Edinburgh in 1954 (Cowan, 1964). Dr Cowan was an individual of tremendous drive and energy, and his services to horticulture were acknowledged by the Royal Horticultural Society (RHS) with the award of the Veitch Memorial Medal in 1951 and the Victoria Medal of Honour in 1955 (Fletcher \& Brown, 1970).

With reference to the task in hand at the recently acquired Benmore a surviving plan and typewritten notes by Dr Cowan divide the garden into 25 compartments before prescribing future recommendations. The following abridged extract refers to the Walled Garden:

The garden is surrounded by a stone wall 8 to $12 \mathrm{ft}$. high and is divided into eight approximately rectangular sections. Several of these are utilised for growing vegetables, others contain shrubs. There is a large greenhouse in the western portion of the garden with smaller houses and a gardener's house on the east. Outside the main wall of the garden is the winter garden stocked with annuals and perennials... 
Too great a proportion of time is given over to edge trimming and the upkeep of herbaceous borders. To reduce work within the walls and so free labour for other work in the policies the following recommendations are made ...

The wide bed by the south wall will be sown down with grass ... to the east of the greenhouses the Cupressus hedges between beds of shrubs shall be removed ... The actual outlay required for upkeep (of glasshouses) is very considerable ... of the main range of (glass) houses the central house is the only part worth preserving ... the central staging should be removed and palms planted ... other (glass) houses along the wall will be dismantled and climbers planted.

The small house on the north wall near the gardener's house will be maintained and heated in winter. (Cowan, c. 1930, pp. 30-32)

Budget considerations and priorities outwith the Walled Garden governed Dr Cowan's strategy. His summary concluded with an overall desire to cut down formal work as far as possible. There are surviving images of Dr Cowan (resplendent in patterned knitwear) supervising the construction of the dry-built west wall following the reduction of the glasshouse suite (Fig. 19).

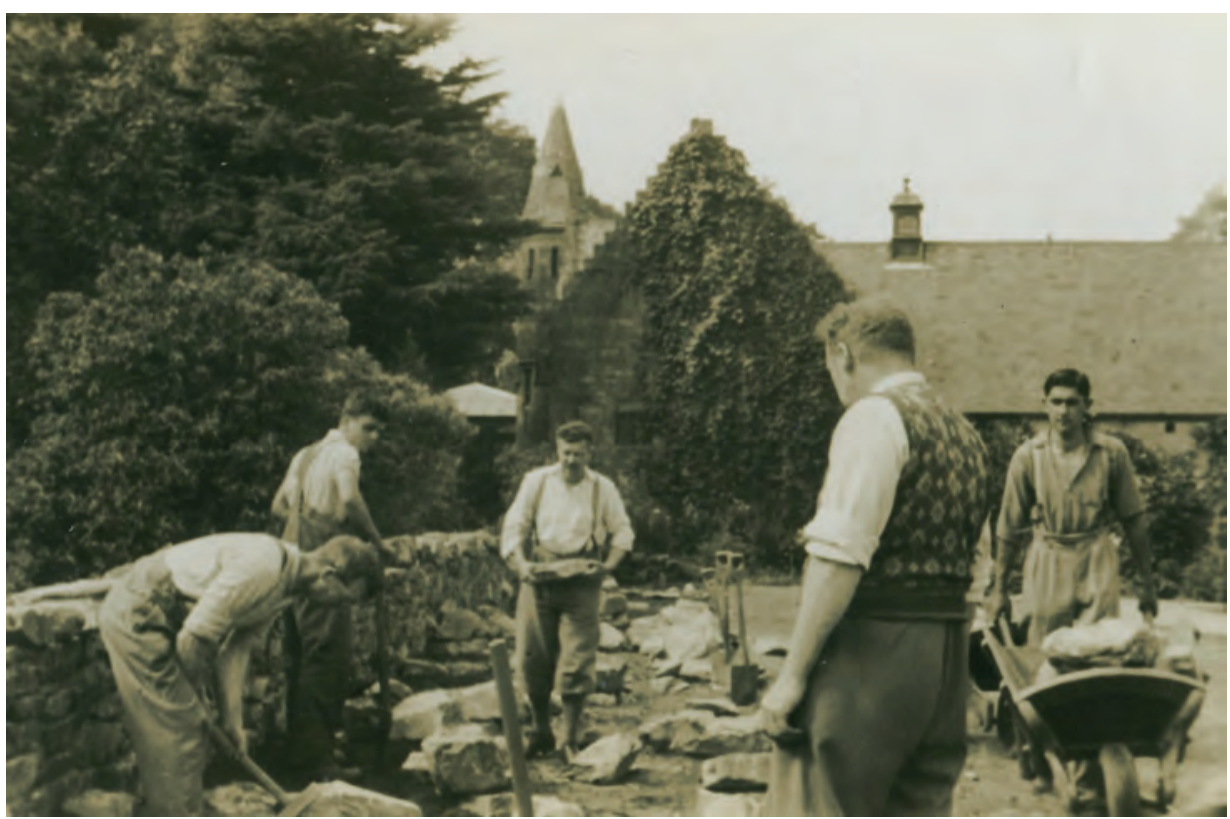

Fig. 19 Black-and-white photo. Construction work supervised by Dr J.M. Cowan, c. 1934. Miscellaneous photograph in Benmore Curator's office, kindly made available by Peter Baxter. 


\section{ATTRACTIONS OF BENMORE}

A 1932 article published in the Journal of the Forestry Commission provides a further description of the Walled Garden shortly after the implementation of the RBGE prescriptive management strategy:

Near the pond is one of the garden gates by which we can enter and pass to the centre walk between fine yew hedges. It would take too long to describe the contents of these five acres; suffice to say innumerable species of flowering shrubs are there - also a wall garden and the old winter garden with ericas, bamboos, primulas, and a showy Magnolia stellata. Near the main entrance is a wall on which are growing very fine specimens such as Aristolochia Sipho, Berberidopsis corallina, Solanum crispum, Wistaria sinensis, Vitis coignetiae, Arbutus Unedo, Schizandra Henryi, Correa alba, Magnolia conspicua, Buddleia globosa, Sophora tetraptera, Choisya ternata.

In front of the greenhouses, which are not heated now and have less hardy shrubs in them, the following species are doing well: Hydrangea paniculata, Liriodendron tulipifera, Rosa Moyesii, Itea ilicifolia, Lithospermum scoparium, Pieris floribunda and Veronica species. (Watson, 1932, pp. 12-13)

\section{BLACK-AND-WHITE FILM 1934}

The continued popularity of Benmore throughout the early 1930s is almost without precedent. A Forestry Commission initiated black-and-white $16 \mathrm{~mm}$ film from 1934 celebrates the house and estate by recording general views and some of the activities of resident forestry trainees. ${ }^{2}$

The 17-minute-long silent film opens with a shot of the main gate and a sign displaying admission charges of sixpence. The Walled Garden footage details the bronze 'Boy with Two Dolphins' fountain and surrounding hedges, the uncovered but still functioning winter garden water feature and an extensively planted vertical garden occupying the external east wall. The linking east wall doorway is still in use. The Walled Garden segment concludes with views of the still complete western glasshouse range and extensive plantings of rhododendron beds.

\section{PUBLICATION OF GARDEN GUIDEBOOK}

The early 1930s saw the compilation of a printed garden guidebook. Published by the Benmore Trust, the booklet featured text by Dr Cowan. Images by Robert Moyes Adam were used to provide extensive black-and-white illustrations. The text confirms contemporary Walled Garden descriptions with the following additions:

2. Forestry Commission 16 mm black-and-white film, 1934. Benmore House \& Estate, NLS Moving Image Archive Reference Number 2413. 
Old fashioned hedges of Yew are draped in summer with the trailing sprays of the crimson-flowered Tropaeolum speciosum. Many of the beds are now used as nurseries, where seedlings and saplings of the choicer trees and shrubs are raised for planting out in the policies when old enough to hold their own ... The paths are bordered with dwarf rhododendrons of the Lapponicum, Sanguineum and Saluenense series ... In the winter garden an assortment of alpines finds lodgement in the crevices of the wall, and in this sheltered enclosure are Magnolia stellata, Platanus orientalis and also a handsome plant of Rosa Hugonis ... Facing this garden and opposite the glass-houses, now open to the public for shelter, is the wild bank. (Cowan, c.1933, p. 5)

The publication of the garden guidebook is also noteworthy for a significant change in terminology. Although reference was previously made to "formal" work within the "walled garden" Dr Cowan now affords precedence to the term "formal garden". Henceforward the site is always referred to as the Formal Garden.

\section{DECLINE}

The outbreak of war in 1939 saw the beginning of an extended period of decline at Benmore, with invasive species infiltrating many planted areas (Younger, 2004). The condition of the Formal Garden throughout this period can only be guessed at.

In the mid-1950s remnants of James Duncan's magnificent Walled Garden were visually recorded for the last time. In a rather unremarkable colour postcard view, an elevated panorama from the west details large areas of mown grass with the surviving yew hedges defining the raised pond and fountain. Well-established conifers occupy a prominent site in front of the last standing sections of the west glasshouse (Fig. 20).

\section{REBIRTH}

In 1956, Richard Shaw (1927-2000), who had trained at the RHS's garden at Wisley, Surrey, was transferred from RBGE to Benmore and placed in charge of a small staff to oversee the rehabilitation of the Garden. Following a nine-year period of service Shaw moved on from Benmore to the Royal Botanic Gardens, Kew, attaining the position of Garden Curator in 1966 (Fletcher \& Brown, 1970). Shaw would continue the role of Garden Curator upon his return to RBGE in 1972 (Bown, 1992).

The 1959 condition of the Formal Garden at Benmore was described in a Garden Guide leaflet:

In the formal garden can be seen herbaceous and shrub borders which are primarily designed to be at their best in July and August. Of particular interest are the individual shrubs planted by the wall flanking the north side of the garden, notably: Berberidopsis corallina, Magnolia denudata, Schizandra 


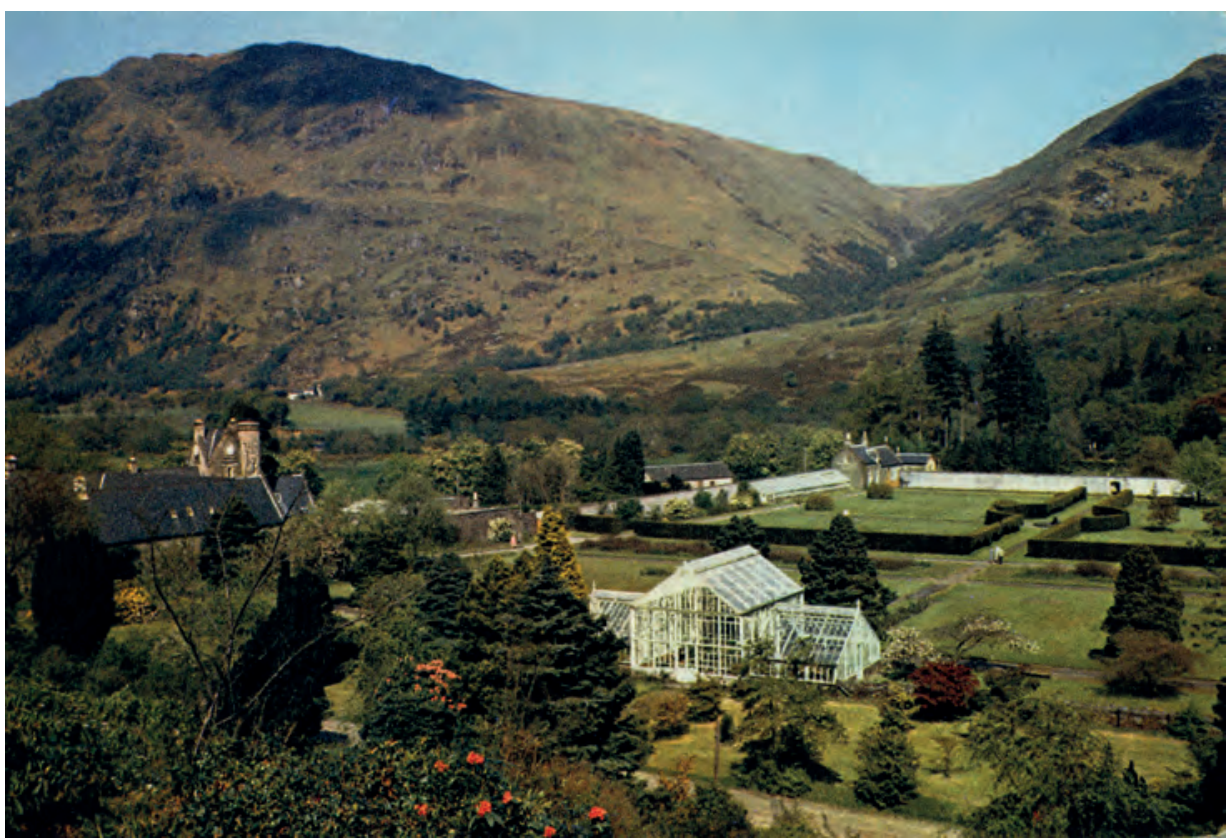

Fig. 20 Colour postcard view from west, the Formal Garden, J. Arthur Dixon, c. 1955. Author's collection.

henryi and Callistemon sp., the latter an example of the crimson flowered "Australian Bottle Brush". Borders of dwarf conifers, and sub-shrubs on both sides of the shelter are attractive at all times of the year.

There are seats provided for those who wish to pause and admire the breath-taking setting which distinguishes this Garden.

At the east end of the Garden, around an unusual fountain, is the Water Garden, where a collection of Astilbes and Spiraeas billow into pinks and whites during June and July. There are also Lilies here, and amongst them the Japanese Golden-rayed Lily, Lilium auratum, which opens its magnificent and heavily scented flowers in September. Another feature of the Water Garden is its wall, which is well clothed with Fuchsia, Veronica, Cotoneaster, Bergenia, Ferns and the yellow Welsh Poppy. (Anon., 1959, sections 2-3)

\section{THE $1960 \mathrm{~S}$}

Several undocumented decisions appear to date from this period, including the relocation of the bronze 'Boy with Two Dolphins' fountain to the nearby garden pond and the blocking-off of the doorway in the east wall, effectively isolating the former winter garden site from Garden visitors.

A familiar theme prompted a major change of strategy regarding long-term maintenance and development: 
In the formal garden, ancient Yew hedges, herbaceous borders full of plants needing staking and tying, formal rose beds and begonia beds, flowering shrubs which need annual pruning, all labour-intensive subjects, but with insufficient labour to maintain them to a decent standard.

They were all scrapped in favour of a collection of garden conifer cultivars and a mixed shrub herbaceous border devoted to subjects which did not require staking or pruning. (Anon., 1989, p. 4)

Gales of hurricane proportions early in the morning of 15 January 1968 demolished the last sections of the west conservatory (Fletcher \& Brown, 1970).

\section{CREATION OF THE CONIFER GARDEN}

In 1964, Arthur Hall (b. 1929) joined the Benmore staff as Foreman and was promoted to Assistant Curator in 1965 (Anon., 1989). Hall was recognised by the RHS in 1988 for outstanding work on the genus Rhododendron at Benmore (Bennell \& Hall, 1992) before retiring from the Garden in 1994.

His arrival at Benmore coincided with the redevelopment of the Formal Garden to display ornamental conifers (Bown, 1992). The new planting arrangement wisely retained the strong west-east and north-south axial layout established by James Duncan almost 100 years previously. A retrospective review provides a partisan summary of the overall redesign concept:

The development of the formal garden was a stroke of genius, being on the one hand a unique reference collection of conifer variants, while on the other hand creating a spectacular contrast with the surrounding countryside.

To appreciate the formal garden fully requires two very different approaches. The first to wander through or sit in it, taking in the remarkable variability and colourfulness of these conifers; the second is to climb Benmore Hill and look down on it from a height, from where its geometry, neatness and verdure appear as an oasis of cultivation among the rugged mountains and apparently impenetrable forests, thus symbolising Benmore itself - a unique balance between garden and wild landscape. (Bown, 1992, pp. 150-151)

There is no doubting the architectural presence or qualities of individual conifer specimens planted in the Formal Garden at this time. The range and origins of the collection were summarised in 1992:

The formal garden contains a collection of nearly 300 garden conifers displaying in one small area the great genetic diversity that has arisen naturally from their forest relatives. The majority derive from either witches' brooms or sports with unusually coloured or juvenile foliage, and must all be propagated 
by cuttings since they will not grow true from seed. Others are naturally dwarf forms from exposed coastal or high montane habitats. Groups of cultivars and varieties belonging to major genera including spruces and junipers dominate each of the borders. Among the range of Chamaecyparis forms, the remarkable diversity to be found within one species, $\mathrm{C}$. lawsoniana, is presented around the southern and eastern boundary walls. (Bennell \& Hall, 1992, p. 19)

The early success of the conifer garden was captured in photographs reproduced in successive printed garden guidebooks from 1974 (Fig. 21) and 1979 (Fig. 22).

\section{PUCK'S HUT}

The late 1960s saw the relocation (with modifications) of the Bayley Balfour memorial rest hut to the Formal Garden at Benmore (Fletcher \& Brown, 1970). The memorial, also known as Puck's Hut (Fig. 23), had been conceived as a tribute to RBGE Regius Keeper Sir Isaac Bayley Balfour (1853-1922). ${ }^{3}$ Designed by Sir Robert Lorimer (1864-1929),

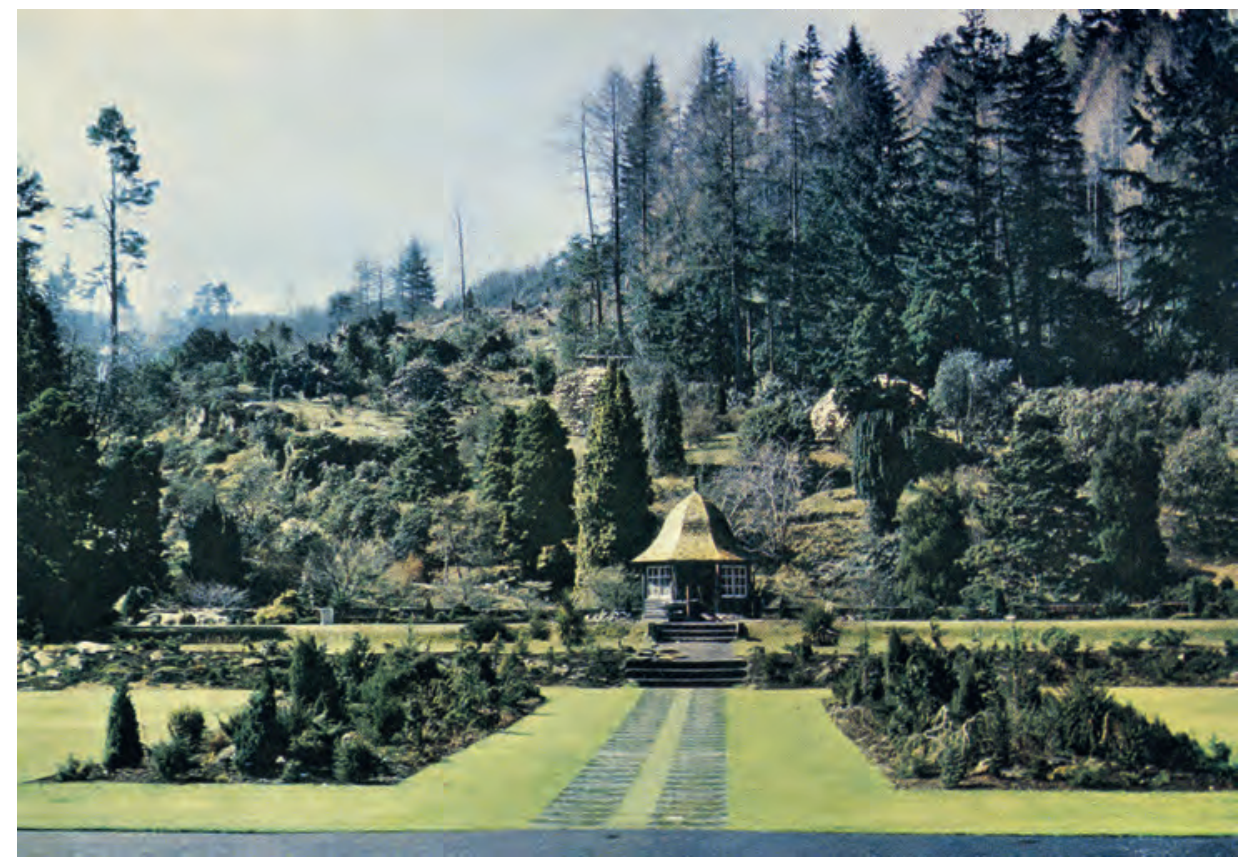

Fig. 21 From Younger Botanic Garden Benmore, Garden Guide (Edinburgh, 1974), p. 7.

3. In addition to Puck's Hut, a memorial tablet commemorating Sir Isaac Bayley Balfour was inserted in a wall near the former glasshouse range at the Edinburgh Garden. Sir Robert Lorimer also designed the tablet and M.R. James advised on the wording of the inscription. The memorial was dismantled when the current Front Range was erected. The inscribed panel is currently built into the outside wall of the RBGE Science Building. RBGE Archives, Benmore Collection, SD55/30, folder relating to the Isaac Bayley Balfour Memorial (1923-1929). 
Fig. 22 From Younger Botanic Garden Benmore, Garden Guide (Edinburgh, 1979), p. 2.

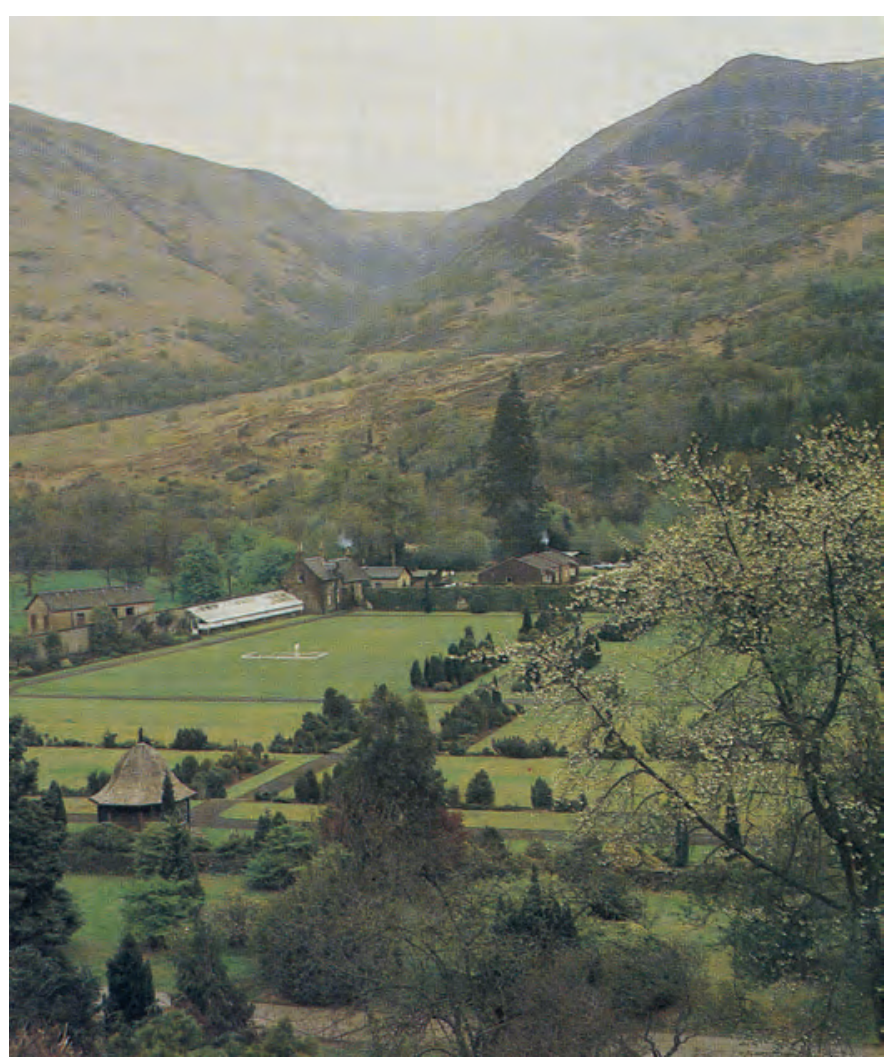

the building was originally positioned within the steep ravine of Puck's Glen in 1928 (Anon., 1928).

The acquisition of the building provided a significant addition to the Formal Garden. Lorimer enjoyed a revered status as a celebrated architect and champion of the Scottish Arts and Crafts movement. A renowned garden designer, he was something of a revivalist, his style characterised by axial vistas, clipped hedges, geometric planting beds and garden ornament (Campbell, 2007). The appeal and positioning of Puck's Hut in the Formal Garden was justly celebrated:

It is exquisitely placed. No more than an octagonal shelter, but a perfect piece of garden architecture, both precise and playful. A cedar-shingled, bell-shaped roof commands the axis yet charms the eye in every chance view glimpsed through the trees. (Walker, 2000, p. 146)

The significant Lorimer connection and recognition of the structure as a unique garden building resulted in Category C listing being awarded to Puck's Hut by Historic Environment Scotland in June 1992. 


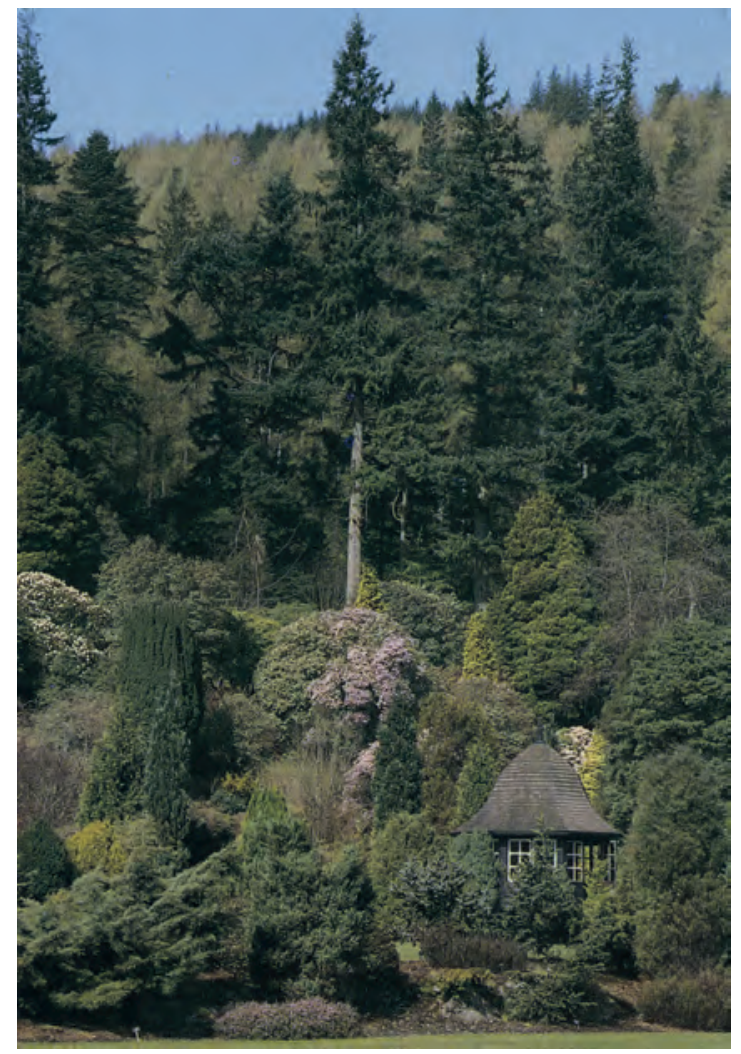

Fig. 23 Colour postcard view, Puck's Hut (Bayley Balfour Memorial) and lower slopes from Formal Garden, Younger Botanic Garden, c. 1990. Author's collection.

\section{COUNTRY LIFE MAGAZINE FEATURE}

In the summer of 1978 popular horticultural writer and journalist Arthur Hellyer (19021993) contributed a significant promotional feature to the pages of Country Life (Hellyer, 1978). Hellyer provides a brief history of Benmore before reviewing the garden and plant collection.

The Formal Garden is described and illustrated with a striking wide-angled blackand-white photograph depicting well-balanced borders of dwarf conifers set against the backdrop of the Eachaig Valley (Fig. 24). An accompanying image details a distant Puck's Hut viewed from the east. In the foreground is the last recorded image of James Duncan's raised ornamental pond featuring what appears to be the Carrara marble centrepiece from the now abandoned former winter garden (Fig. 25).

\section{MATURITY AND LATER DETAILS}

The 1960s redevelopment served the Formal Garden well throughout the remainder of the 20th century. Regular maintenance duties included grass cutting, lawn scarifying and 


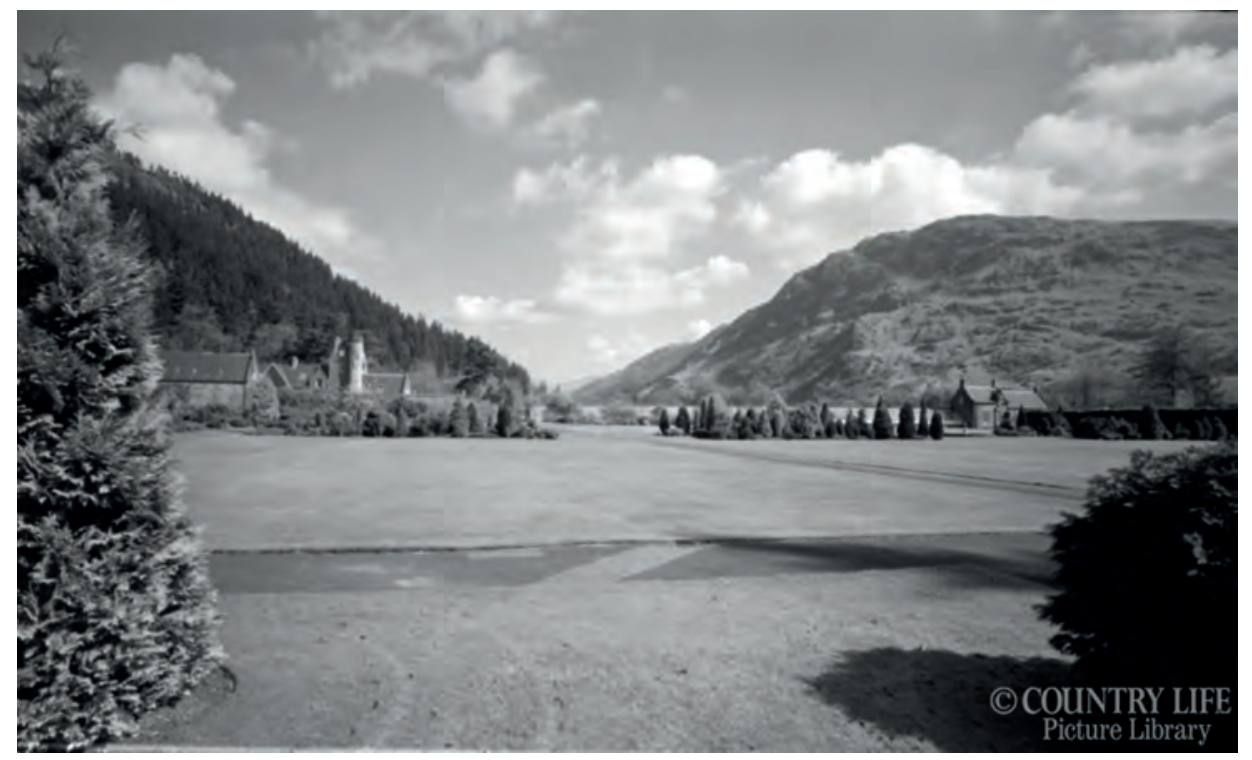

Fig. 24 View across the Formal Garden up the valley of the River Eachaig, 1978. Image: Jonathan M. Gibson/@ Country Life Picture Library.

Fig. 25 The mountainside seen from the Formal Garden through the conifer borders, 1978. Image: Jonathan M. Gibson/C Country Life Picture Library.

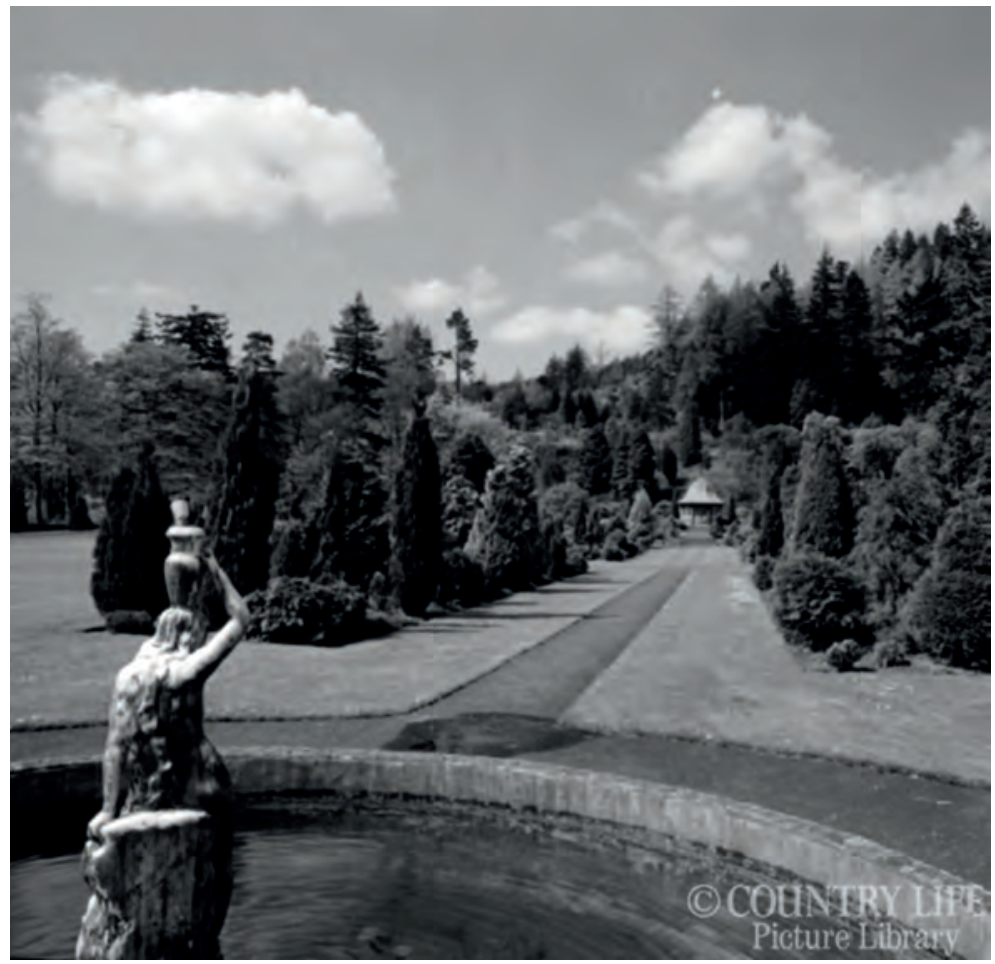


aeration, weed control and edging. Plant records and labelling would form an additional maintenance task.

In 1981, an armillary sphere sundial was positioned halfway down the flagstone walk on the former site of James Duncan's raised pond and ornamental fountain (Anon., 1989). The timepiece, commissioned by the Younger (Benmore) Trust, features a representation of the Milky Way and Earth with signs of the zodiac providing further detail. It commemorates RBGE Regius Keeper Harold Roy Fletcher (1907-1978).

The adjacent Category B listed courtyard buildings were painstakingly rescued from decay by the Property Services Agency Architects and James Taylor Partnership in 1990-19914 (Walker, 2000).

In June 1992, the Walled Garden and Garden Cottage were designated as Category B listed buildings by Historic Environment Scotland. Similar status was also applied to the bronze 'Boy with Two Dolphins'.

The plant collection within the Formal Garden was mapped and added to a computerised database in the late 1990s.

\section{NEW HORIZONS}

The late 20th century saw a change of priorities at Benmore, prompting an ambitious expansion of the living collection outwith the Formal Garden. Distinct geographically themed plantings of wild origin material were carried out between 1987 and 2007 (Levin \& Young, 2011). To accommodate the Chilean collection and create other more general planting opportunities, the Garden acquired additional land from the neighbouring Forestry Commission. This expanded the area of managed landscape from 36.4 to 48.5 ha.

\section{OVERMATURITY AND SUGGESTED SOLUTIONS}

By the start of the 21 st century the conifer collection within the Formal Garden was maturing, with the larger and stronger growing specimens overshadowing or eclipsing more dwarf forms. The planting appeared unbalanced and the original design concept unclear. These problems were sympathetically acknowledged by Peter Daniel (19242015) and Siobhan McDermott in their Benmore Botanic Garden Landscape Assessment \& Development Plan (2006):

As a Formal Garden the assorted planting groups have now become overgrown and dominate its scale in a random way, so much so that the first view the visitor has of it has little to commend it. The visual impression is of large and not very interesting grass areas interspersed with groups of trees and a dull central tarmac path leading nowhere. (Daniel \& McDermott, 2006, p. 32)

4. The project dates $1986-1988$ are more accurately recorded on p. 12 of an undated brochure by PSA Projects - A Division of PSA Services, Argyle House, Edinburgh. 
To stimulate discussion regarding the future of the Formal Garden, Daniel \& McDermott offered the following suggestions:

We propose that traditional elements of formality are re-introduced to make, with careful phasing and alongside much of the existing planting, a series of exciting spaces, vistas and avenues using yew and beech hedging (nowadays more easily maintained) as the primary discipline, with additional planting of fastigiate conifers to reinforce the present pattern ... elsewhere there will be opportunities to develop further attractions, for example a playground, a grass maze, an outdoor space associated with the Courtyard Gallery. Make Puck's Hut a key vista within the Formal Garden leading the visitor towards the hillside garden. The central path could become a formal reflective water canal. (Daniel \& McDermott, 2006, pp. 32-34)

The recommendations were sketched out in a simple plan (Fig. 26).

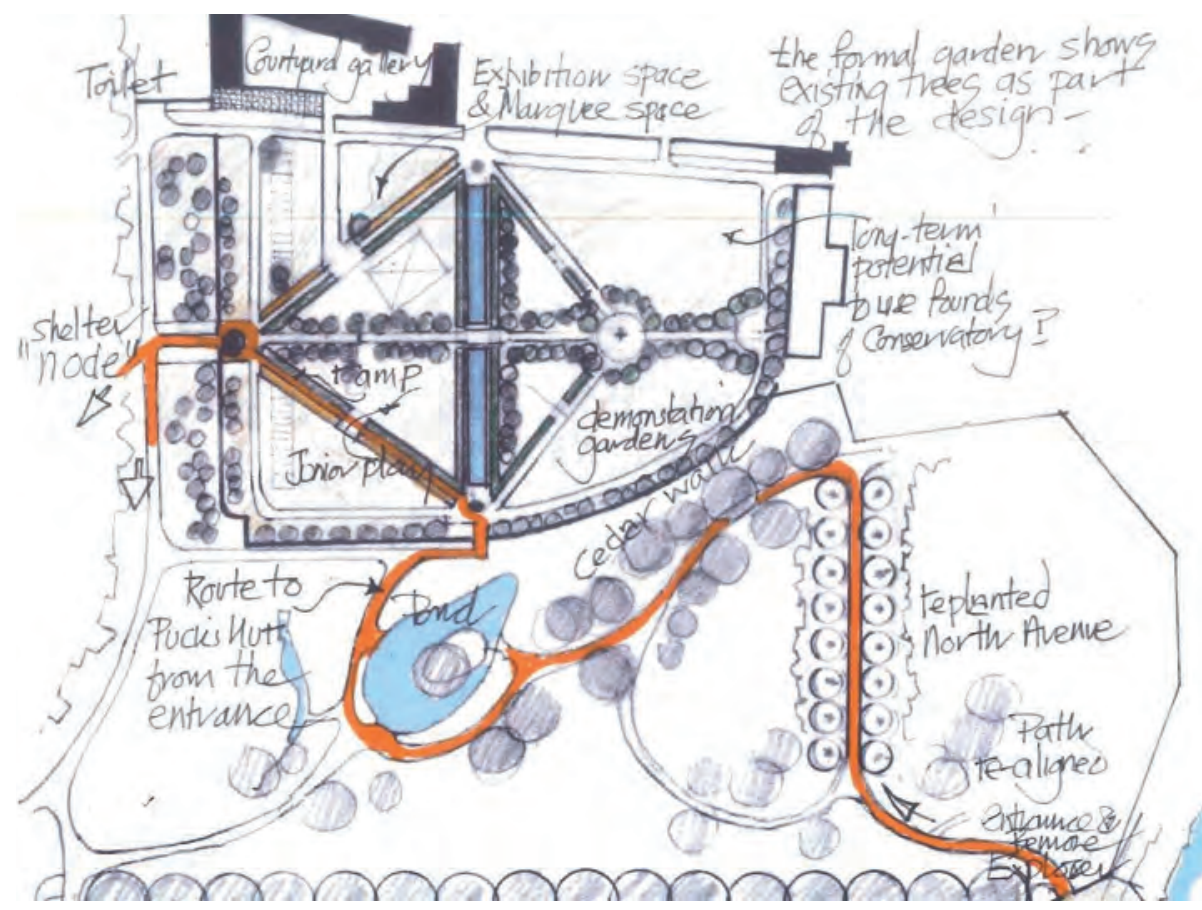

Fig. 26 Formal Garden sketch proposal, Landscape Assessment \& Development Plan, Daniel \& McDermott (2006), p. 33. 


\section{DISEASE}

In 2010, the mature conifer collection within the Formal Garden began to exhibit signs of distress and severe dieback (Peter Baxter, pers. comm.). The pernicious fungal disease Phytophthora cinnamomi was diagnosed, leading to bronzed specimens followed by often rapid tree death (Fig. 27). The narrow range of species represented and close planting arrangements offered little resistance to the aggressive plant pathogen.

The only solution available was the introduction of a sanitation policy. This involved the cutting and burning of infected specimens on site followed by root removal; nonetheless, the eastern half of the Garden succumbed entirely within the space of three years (Fig. 28). Later sporadic outbreaks necessitated further action.

Pathological disorder may have sealed the fate of the conifer collection; redevelopment of the high-profile Formal Garden had already become a topic of discussion.

\section{CONCLUSION}

The Benmore Walled (or Formal) Garden is not directly associated with any famous garden designer. Although a relatively modern garden, it has undergone various modifications and replanting. Despite obscure origins and sporadic gaps, it is remarkably well documented.

The terms 'kitchen garden' and 'walled garden' are often synonymous; historically both terms have applied at Benmore. It is the axial design laid out by James Duncan and

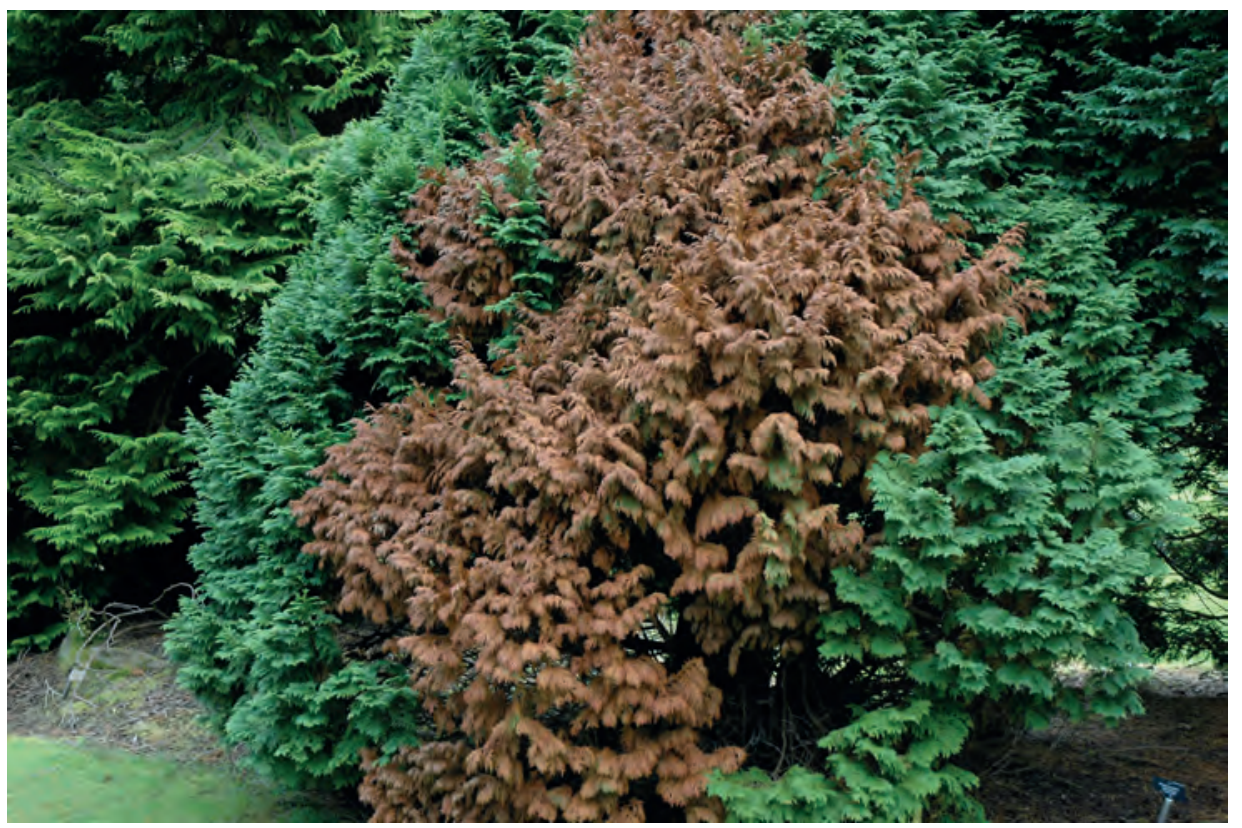

Fig. 27 Conifer displaying symptoms of Phytophthora cinnamomi, August 2011. Photograph: P. Baxter. 


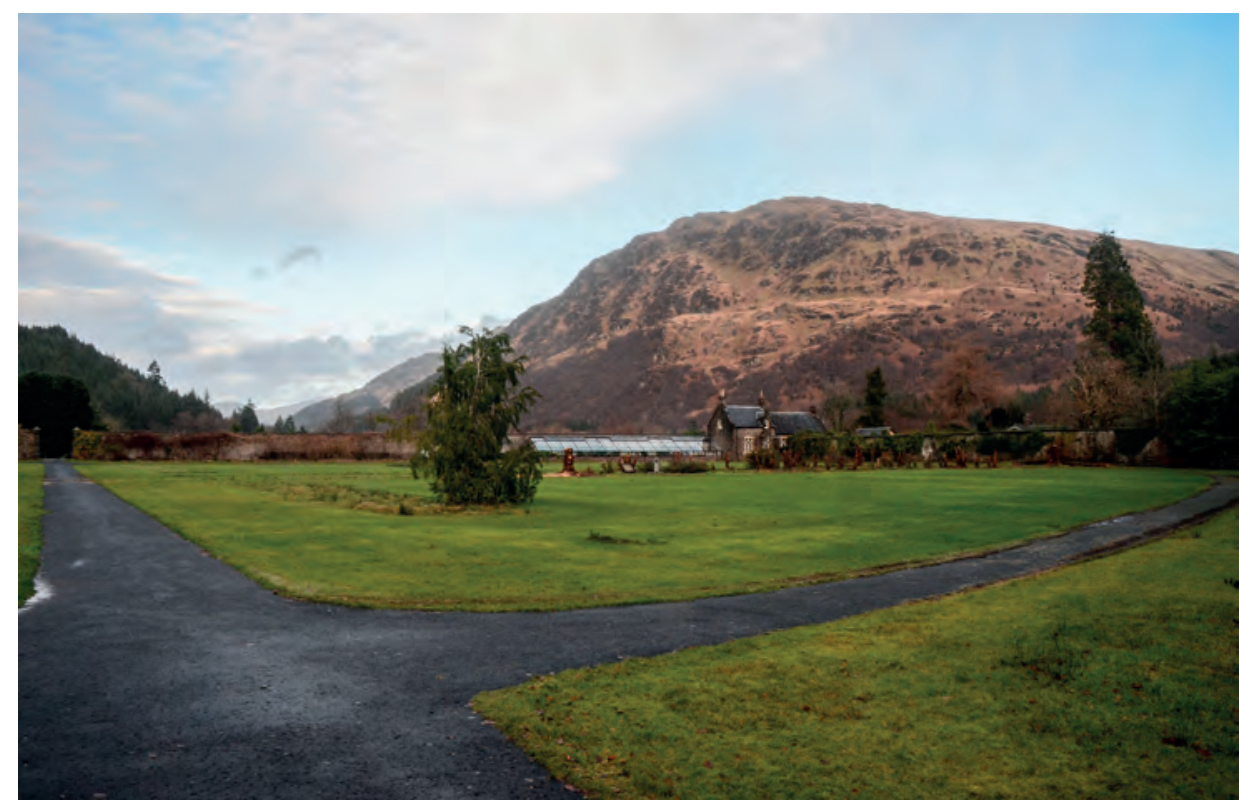

Fig. 28 Clearance of east Formal Garden following outbreak of Phytophthora cinnamomi, December 2013. Photograph: P. Baxter.

his Head Gardener all those years ago which persists and defines the formal aspect. This creates a direct contrast with the woodland style of planting predominant throughout the rest of Benmore and the rugged external landscape beyond.

The opportunity exists to rejuvenate the site and record a further chapter in the continued development of this exceptional and prominent space. It is an opportunity to embrace.

\section{ACKNOWLEDGEMENTS}

The draft form of this article would not have been completed without the individual and collective skills of Graham Hardy (Serials Librarian RBGE), Leonie Paterson (Archivist RBGE), Staff at National Library Scotland, Staff at University of Aberdeen Library Archive, Staff at Glasgow University Library Archive, Peter Baxter (Garden Curator Benmore) and Sybil Gray (Administration Officer Benmore). Special thanks go to Lynsey Wilson (Photographer RBGE) for her help with scanning images. Thank you all for your help, encouragement and enthusiasm.

\section{REFERENCES}

ANON. (1875). A New Fernery. The Garden, 7: 151.

ANON. (1925a). Gift to nation: estate for Forestry Commission. Glasgow Herald, 13 February 1925, p. 9. 
ANON. (1925b). First consignment of plants dispatched to Benmore (typewritten notes dated 6 October 1925). RBGE Library Archive.

ANON. (1928). Scotland's new forest. Announcement of big scheme. New populations predicted. The Bulletin and Scots Pictorial, 14(217), 10 September 1928, p. 6.

ANON. (1959). Benmore: The Younger Botanic Garden. HMSO, Edinburgh.

ANON. (1989). History of Younger Botanic Garden Benmore (typewritten notes from RBGE Trustees Meeting, 17 May 1989). RBGE Library Archive.

BENNELL, A.P. \& HALL, A. (1992). Younger Botanic Garden Benmore. RBGE, Edinburgh.

BGCI (2006). Botanic Gardens Conservation International: News \& Events. Available online: www.bgci.org/news-and-events/news/0181/ (accessed October 2017).

BOWN, D. (1992). 4 Gardens in One: The Royal Botanic Garden Edinburgh. HMSO, London.

BOYD, JAMES \& SONS (1905). An Illustrated Catalogue, James Boyd \& Sons, Horticultural Builders and Heating Engineers Paisley. Copy consulted held in National Library of Scotland, Shelfmark T.116.a.

BROGDEN, W. (1981). The History of Garden Design in Scotland. In: LITTLE, G.A. (ed.) Scotland's Gardens. Spurbooks, Edinburgh, pp. 5-23.

CAMPBELL, K. (2007). Policies and Pleasuances, A Guide to the Gardens of Scotland. Barn Elms Publishing, London.

CAMPBELL, S. (2006). Walled Kitchen Gardens (2nd edn). Shire Publications Ltd, Oxford.

CLERK, D. (1878). On the Agriculture of the County of Argyll. Transactions of the Highland and Agricultural Society of Scotland on the Agriculture, (4)10: 1-104.

COWAN, J.M. (c. 1930). Benmore Gardens by Dunoon Argyll, A Plan for the Development of the Benmore Policies. Unpublished report. RBGE Archive, Edinburgh.

COWAN, J.M. (c. 1933). Benmore Guidebook (n.p.).

COWAN, M. (1964). Inverewe: A Garden in the North-West Highlands. Geoffrey Bles Publishing, London.

COX, E. (1935). A History of Gardening in Scotland. Chatto \& Windus, London.

CURTIS, E.W. (1999). Kibble's Palace. Argyll Publishing, Glendaruel.

DANIEL, P. \& MCDERMOTT, S. (2006). Benmore Botanic Garden: Landscape Assessment \& Development Plan. Unpublished report commissioned by RBGE, Edinburgh.

DAVIS, M. (1996). Thomas H. Mawson \& Garden Design in Argyll and Bute. Local History: The Magazine of Argyll \& Bute Library Service, 1: 5-9.

DINGWALL, C. (1995). Researching Historic Gardens in Scotland: A Guide to Information Sources. Scottish Natural Heritage Review, no. 54. Scottish Natural Heritage, Perth.

FLETCHER, H.R. \& BROWN, W.H. (1970). The Royal Botanic Garden Edinburgh 1670-1970. HMSO, Edinburgh.

GOODE, P., JELLICOE, G., JELLICOE, S. \& LANCASTER, M. (1991). Oxford Companion to Gardens. Oxford University Press, Oxford.

HADFIELD, M. (1979). A History of British Gardening. John Murray Publishers Ltd, London. 
HELLYER, A. (1978). The hills are alive ... the Younger Botanic Garden, Benmore. Country Life, 164(4231): 366-367.

JAMES, H. (1869). OS Book of Reference to the Plan of the Parish of Kilmun, County of Argyll. HMSO, London.

LEVIN, A. \& YOUNG, F. (2011). Benmore Guide Book. RBGE, Edinburgh.

LYALL WATSON, J. AND CO., \& BLAIR AND FINLAY, W.S. (1889). Book of Particulars, Plan, and Photograph of the Magnificent Highland Domain of Benmore, Bernice, \& Kilmun, in Argyllshire. University of Aberdeen Library Archive.

MACKAY, M. (1845). United Parish of Dunoon and Kilmun. The New Statistical Account of Scotland, vol. VII, pt II: Argyll. William Blackwood \& Sons, Edinburgh \& London, pp. 567-631.

PATERSON, L. (2013). How the Garden Grew. RBGE, Edinburgh.

PHILLPOTTS, E. (1906). My Garden. Country Life Library, London.

REID, J. (1988 [1683]). The Scots Gardener. Mainstream Publishing, Edinburgh.

ROBERTSON, P., SHARPLES, J. \& IMRIE, N. (2014). Mackintosh Architecture: Context and Meaning. Available online: www.mackintosh-architecture.gla.ac.uk (accessed October 2017)

STALKER, D. (1883). Plantations of the Estates of Benmore and Kilmun. Transactions of the Highland and Agricultural Society of Scotland, (4)15: 131-142.

WALKER, F. (2000). The Buildings of Scotland: Argyll and Bute. Yale University Press, Newhaven, CT \& London.

WATSON, A.M. (2010). James Duncan, An Enlightened Victorian. RBGE, Edinburgh.

WATSON, H. (1932). Attractions of Benmore. Journal of the Forestry Commission, 11: 10-14.

W.D.B. (1924). Glasgow and West of Scotland Horticultural Society Excursion to Benmore. The Scottish Gardener and Northern Fruitgrower, 1: 33.

WHITE, J. (1930). Benmore. Journal of the Edinburgh Royal Botanic Garden Guild, 2: 59-60.

WRIGHT SMITH, W. (1925). Correspondence between William Wright-Smith and Sir Lionel Earle (Permanent Secretary to the Office of Works 1912-1933). Typewritten letter dated 9 March. RBGE Library Archive, Edinburgh.

YOUNGER, D. (2004). Country House Life in the Highlands, The Younger Family at Benmore, 1889-1929. RBGE, Edinburgh. 


\section{APPENDIX}

The extensive Robert Moyes Adam Photographic Archive compiled between 1902 and 1956 is held at the University of St Andrews Library Special Collections. The following images are relevant to the Benmore Walled Garden:

RMA-F-432, Yew Hedges, Benmore, 1929.

RMA-F-433, Fountain, Rock Garden, Benmore, 1929.

RMA-F-434, Fountain, Rock Garden, Benmore, 1929.

RMA-F-435, The Rock Garden, Benmore, 1929.

RMA-F-436, Gate to Rock Garden, Benmore, 1929.

RMA-F-437, Pergola, Benmore, 1929.

RMA-F-438, Pergola, Benmore, 1929.

RMA-F-439, The Glasshouses, Benmore, 1929.

RMA-F-440, Fountain, Benmore, 1929.

RMA-F-441, The Glasshouses, Benmore, 1929.

RMA-F-442, The Glasshouses, Benmore, 1929.

RMA-F-443, The Glasshouses, Benmore, 1929.

RMA-H-1913, Peach House, Benmore House, 1928.

RMA-H-2158, from Cruach Hill to Holy Loch, 1929.

RMA-H-2159, from over Benmore Policies (from A'Chruach), 1929.

RMA-H-2160, The Benmore Garden (from A'Chruach), 1929.

RMA-H-2161, Benmore Garden, Cowal (from A'Chruach), 1929.

RMA-H-2162, Benmore Garden from Cruach Hill, 1929.

RMA-H-2185, Benmore Gardens and Policies (from Ben Cruach), 1929.

RMA-H-2308, The Gardens, Benmore, 1930.

RMA-H-2309, Rhododendron Hybrids, Benmore, 1930.

RMA-H-2310, The Garden, 1930.

RMA-H-2311, The Garden, 1930.

RMA-H-2312, The Fountain, Benmore, 1930.

RMA-H-2367, The Garden, Benmore, 1930.

RMA-H-2368, The Garden, Benmore, 1930.

RMA-H-2372, Benmore Gardens and Policies (from Ben Ruadh), 1930.

RMA-H-2373, Benmore Gardens and Policies (from Ben Ruadh), 1930.

RMA-H-2374, Benmore and Environs (from Creag Liath), 1930. 
